\title{
Invited review: Organic and conventionally produced milk- An evaluation of factors influencing milk composition
}

\author{
B. H. Schwendel, ${ }^{* 1}$ T. J. Wester, ${ }^{*}$ P. C. H. Morel, ${ }^{*}$ M. H. Tavendale, † C. Deadman, $\ddagger$ N. M. Shadbolt, $\S$ \\ and D. E. Otter\# \\ *Institute of Veterinary, Animal and Biomedical Sciences, Massey University, Tennent Drive, Palmerston North 4474, New Zealand \\ †Animal Nutrition and Health, AgResearch Grasslands Research Centre, Tennent Drive, Palmerston North 4442, New Zealand \\ ¥Fonterra Research Centre Palmerston North, Dairy Farm Road, Palmerston North 4442, New Zealand \\ §Institute of Agriculture and Environment, Massey University, Tennent Drive, Palmerston North 4474, New Zealand \\ \#Food and Bio-based Products, AgResearch Grasslands Research Centre, Tennent Drive, Palmerston North 4442, New Zealand
}

\section{ABSTRACT}

Consumer perception of organic cow milk is associated with the assumption that organic milk differs from conventionally produced milk. The value associated with this difference justifies the premium retail price for organic milk. It includes the perceptions that organic dairy farming is kinder to the environment, animals, and people; that organic milk products are produced without the use of antibiotics, added hormones, synthetic chemicals, and genetic modification; and that they may have potential benefits for human health. Controlled studies investigating whether differences exist between organic and conventionally produced milk have so far been largely equivocal due principally to the complexity of the research question and the number of factors that can influence milk composition. A main complication is that farming practices and their effects differ depending on country, region, year, and season between and within organic and conventional systems. Factors influencing milk composition (e.g., diet, breed, and stage of lactation) have been studied individually, whereas interactions between multiple factors have been largely ignored. Studies that fail to consider that factors other than the farming system (organic vs. conventional) could have caused or contributed to the reported differences in milk composition make it impossible to determine whether a system-related difference exists between organic and conventional milk. Milk fatty acid composition has been a central research area when comparing organic and conventional milk largely because the milk fatty acid profile responds rapidly and is very sensitive to changes in diet. Consequently, the effect of farming practices (high input vs. low input) rather than farming system (organic vs. conventional) determines milk fatty acid profile,

Received May 20, 2014.

Accepted October 29, 2014.

${ }^{1}$ Corresponding author: heike.schwendel@agresearch.co.nz and similar results are seen between low-input organic and low-input conventional milks. This confounds our ability to develop an analytical method to distinguish organic from conventionally produced milk and provide product verification. Lack of research on interactions between several influential factors and differences in trial complexity and consistency between studies (e.g., sampling period, sample size, reporting of experimental conditions) complicate data interpretation and prevent us from making unequivocal conclusions. The first part of this review provides a detailed summary of individual factors known to influence milk composition. The second part presents an overview of studies that have compared organic and conventional milk and discusses their findings within the framework of the various factors presented in part one.

Key words: organic milk, milk composition, pasture, milk fatty acid

\section{INTRODUCTION}

Composition of bovine milk is influenced by many factors related either to the individual animal or to the animal's environment. Elements such as diet (Ferlay et al., 2008; Larsen et al., 2010), breed (Soyeurt et al., 2006; Palladino et al., 2010), individual animal genetics (Soyeurt et al., 2008), stage of lactation (Craninx et al., 2008; Stoop et al., 2009), management (Coppa et al., 2013), and season (Heck et al., 2009), as well as the interactions between them (Macdonald et al., 2008; Piccand et al., 2013; Stergiadis et al., 2013), affect milk composition, with many of the mechanisms behind these effects not fully understood. Therefore, when attempting to study the effect of one specific factor (e.g., diet) on cow milk composition, it is necessary to eliminate other influences. Those factors that cannot be eliminated must be accounted for and their effects considered and minimized.

Currently, there is no evidence that consumption of organic food leads to meaningful nutritional benefits 
for human health (Forman et al., 2012; Załecka et al., 2014). Studies purportedly comparing organic and conventionally produced milk are rife with complications. To be able to determine whether organic milk differs from conventionally produced milk, all factors that influence milk composition must be identical except for the factors that specifically define the farming system (organic or conventional). If more than the system factor varies between compared milk samples, it is difficult to determine whether results derive from the differences between the farming systems or are the consequence of other factors. Recent reviews (Magkos et al., 2003; Dangour et al., 2010; Guéguen and Pascal, 2010; SmithSpangler et al., 2012) remarked on the lack of "true" comparison in studies evaluating organic and conventionally produced foods (including milk and dairy products). Many studies comparing organic and conventionally produced milk are inadequate in their discussion of the factors actually causing the results they present. Commonly, factors that could have contributed to the reported differences (between organic and conventional milk) have not been considered (e.g., differences in diet, breed, and animal health). Most studies proclaiming a comparison of organic and conventional milk used diets that varied in their amount of fresh forage and concentrate for organic and conventional cows, respectively. Consequently, the presented results are most likely related to the effect of the differences in diet, rather than to the fact that cows consumed organic or conventionally produced feed. On the contrary, studies that identify specific production differences for organic and conventional milk (e.g., higher amount of pasture in the diet of organic cows) fail to consider the influence of the farming system (organic or conventional) on their results (Palupi et al., 2012). Additionally, comparisons among studies are problematic because it is difficult to account for any number of variables, including sampling conditions (e.g., frequency of sampling, time of sampling, samples taken from individual cows vs. bulk milk vs. multiple farms), inherent differences in farming systems between regions, levels of input, and even regulatory differences in conventional and organic production between nations.

Regulations regarding organic dairy farming, although similar in principle, vary in detail (Table 1) between countries (e.g., pasture access and use of antibiotics). Therefore, heterogeneity of organic regulations may contribute to the variation in organic milk composition between countries.

The problems outlined above account for the inability of previous studies to reach a consensus on whether compositional differences exist between organic and conventionally produced dairy foods. Consequently, comparison of research studies should be undertaken with the aware- ness that study-specific factors can have a significant effect on animal production and milk composition and might have contributed to reported differences.

This review focuses on the chemical composition of bovine milk and summarizes the variety of different milk components that have been analyzed in regard to their quantitative and qualitative presence in organic and conventionally produced milk. It also aims to show how different milk components are influenced by a variety of individual factors and their interactions, and how the resulting variations can be perceived as differences between organic and conventional milks. It reinforces that these factors need to be considered when evaluating existing studies or designing comparative experiments. Variations within organic and conventional production methods have also created differences that have so far prevented development of a method to test the authenticity of organic milk products. A brief discussion of proposed tests to identify organically produced products is also included.

\section{FACTORS THAT INFLUENCE MILK COMPOSITION}

Numerous and varied factors influence milk yield and composition that, ideally, should be controlled when conducting a trial examining factors that may change milk composition. These factors can seem relatively minor, but they could account for a significant amount of variation. A study conducted by Roche et al. (2009) between 1995 and 2001 showed that the combined influence of weather, herbage quality, and herbage mineral concentration explained up to $22 \%$ of the variation in dairy cattle production. In a different trial, Roesch et al. (2005) compared cow performance from organic and integrated farming systems and found that milk yield positively correlated with breed (especially Holstein), concentrate feeding, routine teat dipping, and greater outdoor access during winter independent of the system. They concluded that lower milk yields (in organic and integrated cows) are a result of the individual animal and on-farm level factors such as breed, nutrition, management, and udder health. A study by Waiblinger et al. (2002), investigating 30 small, family-run dairy farms, suggested that milk production was lower on farms where management had negative attitudes toward interacting with cows during milking. Various factors that influence milk yield, as well as fat, protein, and lactose concentrations, at the farm and individual animal levels are compiled in Table 2.

The factors considered most influential, however, vary depending on study conditions and aims. Stage of lactation, for example, can be neglected when bulk milk samples are collected from a farm with an all-yearround calving system, but it becomes significant when 
Table 1. Country-specific regulations for organic dairy farming in regard to pasture access, forage feeding, and use of antibiotics

\begin{tabular}{|c|c|c|c|c|}
\hline Country & Pasture access & Forage feed & Antibiotics use & Regulation \\
\hline United States & Grazed for $120 \mathrm{~d}$ per year & $\begin{array}{l}\text { During grazing season, } 30 \% \text { of total forage } \\
\text { intake must come from pasture. }\end{array}$ & $\begin{array}{l}\text { Producer must not sell, label, or } \\
\text { represent as organic any edible } \\
\text { product derived from any animal } \\
\text { treated with antibiotics. }\end{array}$ & $\begin{array}{l}\text { Organic foods production act } \\
\text { provisions } 2014 \text { (US Government } \\
\text { Printing Office, 2014) }\end{array}$ \\
\hline Canada & $\begin{array}{l}\text { Pasture access during grazing } \\
\text { season }\end{array}$ & $\begin{array}{l}\text { During grazing season, } 30 \% \text { of total forage } \\
\text { intake must come from pasture. } \\
60 \% \text { of DM in daily rations consists of } \\
\text { hay, fresh/dried fodder, or silage. }\end{array}$ & $\begin{array}{l}\text { Milk withdrawal time. } \\
\text { Animals that require more than } 2 \\
\text { treatments }{ }^{3} \text { shall undergo a } 12-\text { mo } \\
\text { transition period. }\end{array}$ & $\begin{array}{l}\text { Organic Production Systems } \\
\text { General Principles and Management } \\
\text { Standards } 2011 \text { (Canadian General } \\
\text { Standards Board, 2011) }\end{array}$ \\
\hline $\begin{array}{l}\text { European } \\
\text { Union }\end{array}$ & $\begin{array}{l}\text { Pasture access for grazing } \\
\text { whenever conditions allow }\end{array}$ & $\begin{array}{l}60 \% \text { of DM in daily rations consists of } \\
\text { hay, fresh/dried fodder, or silage. } \\
\text { A reduction to } 50 \% \text { for a maximum period } \\
\text { of } 3 \text { mo in early lactation is allowed. }\end{array}$ & $\begin{array}{l}\text { Milk withdrawal time. }{ }^{2} \\
\text { When animals that require more than } \\
3 \text { treatments, }{ }^{3} \text { or more than } 1 \text { course } \\
\text { of treatment if productive lifecycle is } \\
<1 \text { yr, the produce derived from the } \\
\text { animal may not be sold as organic. }\end{array}$ & $\begin{array}{l}\text { Guidance document on European } \\
\text { Union organic Standards } 2010 \\
\text { (Department for Environment Food } \\
\text { and Rural Affairs, 2010) }\end{array}$ \\
\hline Japan & $\begin{array}{l}\text { Pasture access, no less than } \\
\text { twice a week }\end{array}$ & $\begin{array}{l}\text { Feeds other than fresh or dried fodder or } \\
\text { silage are less than } 50 \% \text { of the average } \\
\text { feed intake, in dry weight. }\end{array}$ & $\begin{array}{l}\text { Prescribed drugs or antibiotics } \\
\text { are used only when therapy with } \\
\text { veterinary drugs other than these is } \\
\text { not effective. }\end{array}$ & $\begin{array}{l}\text { Japanese Agricultural Standard for } \\
\text { Organic Livestock Products, } 2005 \\
\text { (Ministry of Agriculture Forestry } \\
\text { and Fisheries) }\end{array}$ \\
\hline New Zealand & $\begin{array}{l}\text { Ruminants must be grazed } \\
\text { throughout the grazing season } \\
150 \mathrm{~d}\end{array}$ & $\begin{array}{l}\text { For herbivores, a minimum of } 50 \% \text { of feed } \\
\text { must come from pasture. }\end{array}$ & $\begin{array}{l}\text { Use of synthetic allopathic veterinary } \\
\text { drugs or antibiotics will cause the } \\
\text { animal to lose its organic status. }\end{array}$ & $\begin{array}{l}\text { AsureQuality Organic Standard } \\
\text { For Primary Producers, } 2013 \\
(\text { AsureQuality, 2013) }\end{array}$ \\
\hline Australia & $\begin{array}{l}\text { Grazing of animals in natural/ } \\
\text { rangeland areas is considered } \\
\text { part of an organic production } \\
\text { system }\end{array}$ & & $\begin{array}{l}\text { After treatment with allopathic } \\
\text { veterinary drugs or antibiotics, the } \\
\text { products can be marketed as organic } \\
\text { or bio-dynamic after a minimum } \\
\text { management period of } 180 \mathrm{~d} \text {. }\end{array}$ & $\begin{array}{l}\text { National Standard for Organic } \\
\text { and Bio-Dynamic Produce, } 2013 \\
\text { (Organic Industry Standards and } \\
\text { Certification Committee, 2013) }\end{array}$ \\
\hline
\end{tabular}

Organic livestock standards for producers are compulsory.

${ }^{3}$ Treatments $=$ combined parasiticides and antibiotics per year.

${ }^{4}$ Organic livestock standards for producers are voluntary.

${ }^{5}$ Several organic livestock standards, which are voluntary and chosen by farmer according to their organic production style. 
milk samples of individual animals are taken or when block calving is practiced (Nantapo et al., 2014). As major influences are accounted for and controlled (e.g., cows in one trial are all of one breed, with similar genetics, at the same stage of lactation, fed similar diets), previously minor factors (e.g., pasture composition) become more important.

Analysis and (potential) alteration of milk FA composition are key areas of dairy research because of the rapid response of FA profile to changes in diet. Other factors influential for milk FA composition are breed, energy status, stage of lactation, udder health, and season. The latter predominantly reflects alterations in diet, especially when these are rich in forage. Chemical and botanical composition of fresh forages varies throughout the seasons, and conservation for hay or silage affects the nutritional value of forages. The seasonal transition of dairy cows from outdoor grazing to indoor housing and the accompanying change in diet can be observed in milk composition (Larsen et al., 2010; Kuczyńska et al., 2012). The effects of breed and season on milk fat composition are summarized in Table 3, and the effects of different forages on milk FA are listed in Table 4.

\section{CONVENTIONAL VERSUS ORGANIC MILK: MAIN COMPONENTS}

\section{Milk Yield}

Despite the existence of highly specialized, grasslandbased, organic farms with cows producing more than 9,000 kg of fluid milk per year (Muller-Lindenlauf et al., 2010), milk production from organically reared cows is lower, on average, than that from conventional cows (Sundberg et al., 2009). These differences are significant, with organic herds achieving 85\% (range: 72 to $91 \%$ ) of the yields recorded for conventional herds (Bilik and Lopuszanska-Rusek, 2010; Müller and Sauerwein, 2010; Stiglbauer et al., 2013). Decreased production under organic management can be traced to lower energy intake, through either less concentrate feeding (Garmo et al., 2010; Stiglbauer et al. 2013) or lower energy content in forages from organic systems. This is exemplified by Gruber et al. (2001), who conducted a 6-yr study with nearly identical diets for organic and conventional cows. They demonstrated that milk yields per cow and year were identical for both herds, but milk production per area grazed was reduced in the organic herd because of lower DM yields from organic pasture and, therefore, lower stocking rates per hectare. Consequently, diets similar in composition and ME content had the same effect on milk production, independent of whether the farming system was organic or conventional.

\section{Milk Fat Content}

Results of research studies examining the fat content in organic and conventional milks are ambivalent. Zagorska and Ciprovica (2008) and Anacker (2007) found increased fat content in organic milk, whereas trials undertaken by Sundberg et al. (2009), Hanus et al. (2008b), and Kuczyńska et al. (2012) observed higher fat percentage in conventional milk. Samples of retail milk collected during October and November 2006 in the United States showed no significant difference for fat percentage between the 2 milk varieties (Vicini et al., 2008). This result might be due to the federal standards for butterfat content for fluid milk products. Müller and Sauerwein (2010) analyzed bulk milk samples of 35 organic and 33 conventional farms during 2002 and 2004 and reported similar amounts of milk fat between the 2 farming systems. Reasons for the reported differences can be diverse, with only a few publications mentioning potential causes. Higher fat concentration in milk from organic compared with conventional farms could have been caused by a preference for non-Holstein breeds in organic herds (Nauta et al., 2009), resulting in a higher number of Jersey and other breeds (Palladino et al., 2010). An increase in starch-based concentrates has been associated with a decline in milk fat concentration. Greater amounts of starch-based concentrates are commonly associated with diets of conventionally farmed dairy cows compared with organic cows (Rosati and Aumaitre, 2004), because organic farming regulations restrict the usage of concentrates. Alternatively, an increase in milk fat percentage in milk from conventional farms may indicate a diet enriched with fat supplements (Vyas et al., 2012; Lock et al., 2013). A negative energy balance, predominantly found during the early stages of lactation and the winter period in low-input organic cows (Trachsel et al., 2000), might also affect fat percentage in milk (Gross et al., 2011). Additionally, a higher parity average (Craninx et al., 2008), variations in heritability (Soyeurt et al., 2007), and genotype (Coleman et al., 2010) can all be reflected in milk fat percentage. One result of inadequate descriptions of experimental trials is that conclusions from these studies need to be interpreted cautiously. Table 5 compiles several studies in which organic and conventionally produced milks have been compared concerning their fat, protein, and lactose contents and lists the reported causes, as proposed by the authors, for any differences.

\section{Milk Fat-Individual FA}

The effect of bovine milk fat on human health cannot generally be described as favorable or unfavorable, and 
Table 2. Summary of factors influencing milk yield, fat, protein, and lactose concentrations ${ }^{1}$

\begin{tabular}{|c|c|c|c|c|c|c|c|c|}
\hline Factor & Milk yield & Reference & Fat $\%$ & Reference & Protein $\%$ & Reference & Lactose $\%$ & Reference \\
\hline Altitude & & & $\begin{array}{l}\text { Higher in } \\
\text { highland vs. } \\
\text { lowland }\end{array}$ & Bartl et al. (2008) & & & & \\
\hline \multirow[t]{4}{*}{ Breed } & \multirow{4}{*}{$\begin{array}{l}\text { Higher in } \\
\text { Holstein vs. } \\
\text { Simmental } \\
\text { Higher in HF vs. } \\
\text { Jersey } \\
\text { Higher in HF } \\
\text { vs. Jersey and } \\
\text { Brown Swiss }\end{array}$} & $\begin{array}{l}\text { Roesch et al. } \\
(2005)\end{array}$ & \multirow{3}{*}{$\begin{array}{l}\text { Higher in Jersey } \\
\text { vs. DF, MRY, } \\
\text { and GWH } \\
\text { Higher in } \\
\text { Minhota vs. HF } \\
\text { Higher in Jersey } \\
\text { vs. HF }\end{array}$} & $\begin{array}{l}\text { Maurice-Van } \\
\text { Eijndhoven et al. } \\
(2011)\end{array}$ & \multirow{3}{*}{$\begin{array}{l}\text { Highest in } \\
\text { Jersey, lowest } \\
\text { in DF } \\
\text { Higher in } \\
\text { Jersey vs. HF } \\
\text { Higher in } \\
\text { Jersey vs. } \\
\text { Holstein }\end{array}$} & $\begin{array}{l}\text { Maurice-Van } \\
\text { Eijndhoven et } \\
\text { al. }(2011)\end{array}$ & \multirow[t]{5}{*}{$\begin{array}{l}\text { Higher in Brown } \\
\text { Swiss vs. Jersey }\end{array}$} & \multirow[t]{4}{*}{ Carroll et al. (2006) } \\
\hline & & $\begin{array}{l}\text { Palladino et al. } \\
(2010)\end{array}$ & & $\begin{array}{l}\text { Ramalho et al. } \\
(2012)\end{array}$ & & $\begin{array}{l}\text { Palladino et al. } \\
(2010)\end{array}$ & & \\
\hline & & $\begin{array}{l}\text { Carroll et al. } \\
(2006)\end{array}$ & & $\begin{array}{l}\text { Palladino et al. } \\
(2010)\end{array}$ & & $\begin{array}{l}\text { Croissant et al. } \\
(2007)\end{array}$ & & \\
\hline & & & $\begin{array}{l}\text { Higher in Jersey } \\
\text { vs. Holstein }\end{array}$ & $\begin{array}{l}\text { Croissant et al. } \\
(2007)\end{array}$ & $\begin{array}{l}\text { Higher in } \\
\text { Brown Swiss } \\
\text { vs. Holstein }\end{array}$ & $\begin{array}{l}\text { Carroll et al. } \\
(2006)\end{array}$ & & \\
\hline Fertilizer & & & & & $\begin{array}{l}\text { Lower with } \\
\text { higher N } \\
\text { application }\end{array}$ & $\begin{array}{l}\text { Hermansen } \\
\text { et al. (1994); } \\
\text { Mackle et al. } \\
(1996)\end{array}$ & & \\
\hline $\begin{array}{l}\text { Grazing } \\
\text { allocation } \\
\text { (frequency) }\end{array}$ & $\begin{array}{l}\text { Higher if } \\
\text { allocation every } \\
\text { day vs. every } \\
\text { fourth day }\end{array}$ & $\begin{array}{l}\text { Abrahamse et al. } \\
(2008)\end{array}$ & $\begin{array}{l}\text { Higher for } \\
\text { allocation every } \\
\text { fourth day vs. } \\
\text { every day }\end{array}$ & $\begin{array}{l}\text { Abrahamse et al. } \\
(2008)\end{array}$ & $\begin{array}{l}\text { Higher if } \\
\text { allocation every } \\
\text { fourth day vs. } \\
\text { every day }\end{array}$ & $\begin{array}{l}\text { Abrahamse et } \\
\text { al. (2008) }\end{array}$ & NS & $\begin{array}{l}\text { Abrahamse et al. } \\
(2008)\end{array}$ \\
\hline $\begin{array}{l}\text { Grazing high } \\
\text { sugar grasses }\end{array}$ & $\begin{array}{l}\text { Positively } \\
\text { correlated }\end{array}$ & $\begin{array}{l}\text { Miller et al. } \\
(2001)\end{array}$ & & & $\begin{array}{l}\text { Positively } \\
\text { correlated }\end{array}$ & $\begin{array}{l}\text { Roche et al. } \\
(2009)\end{array}$ & & \\
\hline \multirow[t]{2}{*}{$\begin{array}{l}\text { Grazing } \\
\text { pasture }\end{array}$} & $\begin{array}{l}\text { Lower vs. } \\
\text { concentrate }\end{array}$ & $\begin{array}{l}\text { Coleman et al. } \\
(2010)\end{array}$ & NS & $\begin{array}{l}\text { Coleman et al. } \\
(2010)\end{array}$ & NS & $\begin{array}{l}\text { Croissant et } \\
\text { al. (2007); } \\
\text { Coleman et al. } \\
(2010)\end{array}$ & Unknown & $\begin{array}{l}\text { Coleman et al. } \\
(2010)\end{array}$ \\
\hline & & & Lower vs. TMR & $\begin{array}{l}\text { Croissant et al. } \\
(2007)\end{array}$ & & & & \\
\hline \multirow[t]{2}{*}{ Genotype } & $\begin{array}{l}\text { Higher in High } \\
\text { NA vs. High NZ } \\
\text { and Low NA }{ }^{2}\end{array}$ & $\begin{array}{l}\text { Coleman et al. } \\
(2010)\end{array}$ & $\begin{array}{l}\text { Higher in High } \\
\text { NZ vs. High NA } \\
\text { and Low NA }\end{array}$ & $\begin{array}{l}\text { Coleman et al. } \\
(2010)\end{array}$ & $\begin{array}{l}\text { Higher in High } \\
\text { NZ vs. High } \\
\text { NA and Low } \\
\text { NA }\end{array}$ & $\begin{array}{l}\text { Coleman et al. } \\
(2010)\end{array}$ & $\begin{array}{l}\text { Higher in High NZ } \\
\text { vs. High NA and } \\
\text { Low NA }\end{array}$ & $\begin{array}{l}\text { Coleman et al. } \\
(2010)\end{array}$ \\
\hline & $\begin{array}{l}\text { Higher in NA90 } \\
\text { than NZ90 }\end{array}$ & $\begin{array}{l}\text { Macdonald et al. } \\
(2008)\end{array}$ & $\begin{array}{l}\text { Higher in NZ90 } \\
\text { than NA90 }\end{array}$ & $\begin{array}{l}\text { Macdonald et al. } \\
\text { (2008) }\end{array}$ & $\begin{array}{l}\text { Higher in NZ90 } \\
\text { than NA90 }\end{array}$ & $\begin{array}{l}\text { Macdonald et } \\
\text { al. (2008) }\end{array}$ & $\begin{array}{l}\text { Higher in NZ90 } \\
\text { than NA90 }\end{array}$ & $\begin{array}{l}\text { Macdonald et al. } \\
(2008)\end{array}$ \\
\hline Heritability & Correlated & $\begin{array}{l}\text { Soyeurt et al. } \\
(2007)\end{array}$ & Correlated & $\begin{array}{l}\text { Soyeurt et al. } \\
(2007)\end{array}$ & Correlated & $\begin{array}{l}\text { Soyeurt et al. } \\
(2007)\end{array}$ & & \\
\hline $\begin{array}{l}\text { Management } \\
\text { attitude }\end{array}$ & $\begin{array}{l}\text { Positively } \\
\text { correlated }\end{array}$ & $\begin{array}{l}\text { Waiblinger et al. } \\
(2002)\end{array}$ & & & & & & \\
\hline Parity & Higher & $\begin{array}{l}\text { Roesch et al. } \\
\text { (2005); Craninx } \\
\text { et al. (2008) }\end{array}$ & Higher & $\begin{array}{l}\text { Craninx et al. } \\
(2008)\end{array}$ & & & & \\
\hline \multirow[t]{2}{*}{ Season } & & & $\begin{array}{l}\text { Minimum in } \\
\text { summer }\end{array}$ & $\begin{array}{l}\text { Heck et al. (2009); } \\
\text { Larsen et al. } \\
(2012) \text {; Stergiadis } \\
\text { et al. (2013) }\end{array}$ & $\begin{array}{l}\text { Minimum in } \\
\text { summer }\end{array}$ & $\begin{array}{l}\text { Heck et al. } \\
(2009)\end{array}$ & $\begin{array}{l}\text { Minimum in } \\
\text { autumn }\end{array}$ & Heck et al. (2009) \\
\hline & & & & & NS & $\begin{array}{l}\text { Larsen et } \\
\text { al. (2012); } \\
\text { Stergiadis et al. } \\
(2013)\end{array}$ & & \\
\hline SCC & $\begin{array}{l}\text { Negatively } \\
\text { correlated }\end{array}$ & $\begin{array}{l}\text { Maréchal et al. } \\
(2011)\end{array}$ & & & $\begin{array}{l}\text { Negatively } \\
\text { correlated }\end{array}$ & $\begin{array}{l}\text { Ballou et al. } \\
(1995)\end{array}$ & $\begin{array}{l}\text { Negatively } \\
\text { correlated }\end{array}$ & $\begin{array}{l}\text { Auldist et al. } \\
(1998)\end{array}$ \\
\hline
\end{tabular}




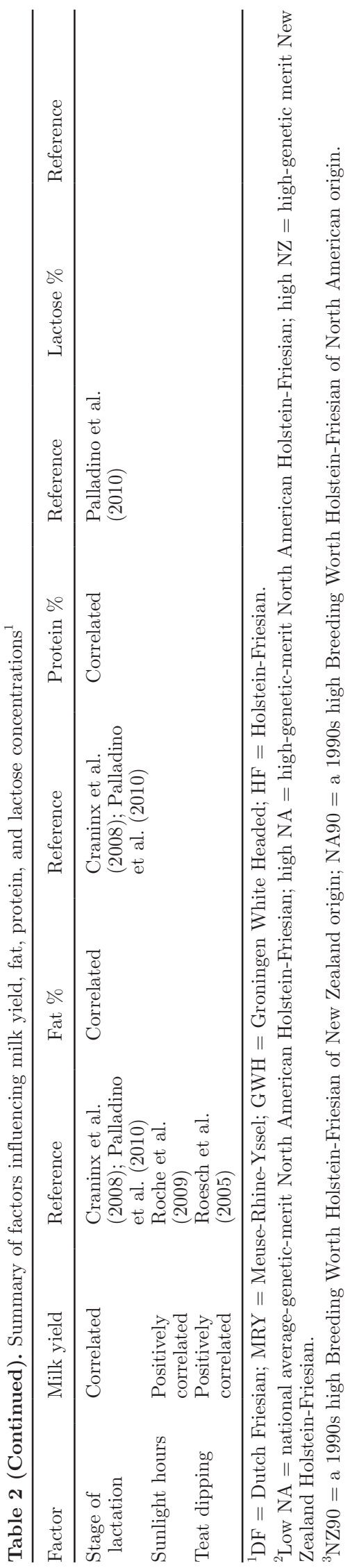

the biological function of each FA should be considered separately (Arnold and Jahreis, 2011). However, much research is currently focused on trying to alter milk FA composition to create a FA profile that is considered more desirable for human health. Two common approaches are to influence milk FA composition through dietary changes or to genetically select cows with a more preferable milk FA profile (Bilal et al., 2012). A low ratio of n-6 to n-3 FA, for example, is beneficial for human health. Typically, the amount of n-6 FA in Western diets is too high, with possible negative consequences (e.g., cardiovascular disease, cancer, and inflammatory and autoimmune diseases; Simopoulos, 2003). Current recommendations regarding the dietary ratio of n-6:n-3 FA target $1: 1$ or $2: 1$, but even a $4: 1$ ratio was found to have a positive effect on asthma patients (Simopoulos, 2003) and decreased mortality in patients with a previous myocardial infarction (Simopoulos, 2010). The n-6:n-3 ratio in bovine milk essentially describes the concentrations of linoleic acid (LA) versus $\alpha$-linolenic acid (ALA), as they represent the most abundant n-6 and n-3 FA. Forage is rich in ALA, whereas cereals (e.g., barley, maize, oats, and soybean) contain higher amounts of LA (Khiaosa-Ard et al., 2010). A lower n6:n-3 ratio is therefore indicative of a forage-based diet.

The concentrations of individual FA in milk fat are influenced by cow breed (Croissant et al., 2007), stage of lactation (Craninx et al., 2008; Nantapo et al., 2014), genetics (Soyeurt et al., 2008), and diet. Diet is especially relevant when comparing concentrate-fed and pasture-based systems. Milk FA composition in pasture-based systems is, additionally, subject to seasonal variations that influence the quantity and quality of available forages. Specific characteristics of forage diets have been widely studied. Adler et al. (2013), for example, compared long-term and short-term grassland management. The pasture composition on long-term organic farms showed a lower proportion of legumes (Fabaceae) and a higher proportion of other dicotyledon families compared with short-term organic farms. Differences in FA composition in milk from 2 organic systems were found for C9:0 to C12:0 and explained by the differences in pasture composition. Similarly, Baars et al. (2012) observed significant differences for C4:0 to C11:0 FA in milk samples from cows fed hay of pasture or hay of ley. This exemplifies how minor dietary differences can affect milk FA composition. Variation in milk FA composition between different breeds has been documented by several researchers. Maurice-Van Eijndhoven et al. (2011) compared 4 cattle breeds (Dutch Friesian, Meuse-Rhine-Yssel, Groningen White Headed, and Jersey) in the Netherlands and found significant differences in total fat percentage as well as in the concentration of short- and medium-chain FA (SMCFA), 
Table 3. Effect of breed and season on individual milk fatty acids ${ }^{1}$

\begin{tabular}{|c|c|c|c|c|}
\hline \multirow[b]{2}{*}{ Fatty $\operatorname{acid}^{2}$} & \multicolumn{2}{|c|}{ Breed } & \multicolumn{2}{|c|}{ Season } \\
\hline & Effect & Reference & Effect & Reference \\
\hline \multicolumn{5}{|l|}{ Even-chain SFA } \\
\hline \multirow[t]{5}{*}{ C4:0 (butyric acid) } & $\begin{array}{l}\text { Higher for DF than MRY, GWH, } \\
\text { and Jersey }\end{array}$ & Maurice-Van Eijndhoven et al. (2011) & NS & Palladino et al. (2010) \\
\hline & Higher for Brown Swiss than Jersey & Carroll et al. (2006) & NS, for herbage & Larsen et al. (2010) \\
\hline & & & Higher in winter & Revello Chion et al. (2010) \\
\hline & & & NS, spring or winter & Rego et al. (2008) \\
\hline & & & Lower in winter with maize silage & Larsen et al. (2010) \\
\hline \multirow[t]{3}{*}{ C6:0 (caproic acid) } & $\begin{array}{l}\text { Higher for DF and MRY than for } \\
\text { GWH and Jersey }\end{array}$ & Maurice-Van Eijndhoven et al. (2011) & NS & Palladino et al. (2010) \\
\hline & Higher for Jersey than Brown Swiss & Carroll et al. (2006) & NS, spring or winter & Rego et al. (2008) \\
\hline & & & Higher in winter & Revello Chion et al. (2010) \\
\hline \multirow[t]{3}{*}{ C8:0 (caprylic acid) } & Holstein lower than Jersey & Croissant et al. (2007) & $\begin{array}{l}\text { Lower in summer } \\
\text { NS, for herbage }\end{array}$ & $\begin{array}{l}\text { Palladino et al. (2010) } \\
\text { Larsen et al. (2010) }\end{array}$ \\
\hline & NS between Minhota and HF & Ramalho et al. (2012) & NS, spring or winter & Rego et al. (2008) \\
\hline & $\begin{array}{l}\text { Higher for DF and MRY than } \\
\text { GWH and Jersey }\end{array}$ & Maurice-Van Eijndhoven et al. (2011) & Higher in winter & Revello Chion et al. (2010) \\
\hline \multirow[t]{4}{*}{ C10:0 (capric acid) } & Holstein lower than Jersey & Croissant et al. (2007) & Lower in summer & Palladino et al. (2010) \\
\hline & Minhota lower than HF & Ramalho et al. (2012) & Higher in spring than winter & Rego et al. (2008) \\
\hline & Lowest for GWH; highest for DF & Maurice-Van Eijndhoven et al. (2011) & Higher in winter & Revello Chion et al. (2010) \\
\hline & $\begin{array}{l}\text { NS between Holstein, Jersey, and } \\
\text { Brown Swiss }\end{array}$ & Carroll et al. (2006) & & \\
\hline \multirow[t]{4}{*}{ C12:0 (lauric acid) } & Holstein lower than Jersey & Croissant et al. (2007) & Lower in summer & Palladino et al. (2010) \\
\hline & Minhota lower than HF & Ramalho et al. (2012) & Higher in spring than winter & Rego et al. (2008) \\
\hline & Higher for DF and MRY than & Maurice-Van Eijndhoven et al. (2011) & Higher in winter & Revello Chion et al. (2010) \\
\hline & $\begin{array}{l}\text { GWH and Jersey } \\
\text { NS between Holstein, Jersey, and } \\
\text { Brown Swiss }\end{array}$ & Carroll et al. (2006) & & \\
\hline \multirow[t]{3}{*}{ C14:0 (myristic acid) } & $\begin{array}{l}\text { Higher for DF and MRY than } \\
\text { GWH and Jersey }\end{array}$ & Maurice-Van Eijndhoven et al. (2011) & Lower in summer & Palladino et al. (2010) \\
\hline & Minhota lower than HF & Ramalho et al. (2012) & Higher in winter & Revello Chion et al. (2010) \\
\hline & $\begin{array}{l}\text { NS between Holstein, Jersey, and } \\
\text { Brown Swiss }\end{array}$ & Carroll et al. (2006) & $\begin{array}{l}\text { Highest in winter, lowest May to } \\
\text { July }\end{array}$ & Kliem et al. (2013) \\
\hline \multirow[t]{5}{*}{ C16:0 (palmitic acid) } & HF lower than Jersey & Palladino et al. (2010) & NS & Palladino et al. (2010) \\
\hline & NS between Minhota and HF & Ramalho et al. (2012) & NS & Revello Chion et al. (2010) \\
\hline & Lowest for GWH; highest for Jersey & Maurice-Van Eijndhoven et al. (2011) & $\begin{array}{l}\text { May higher than August when } \\
\text { lower content of lucerne }\end{array}$ & Larsen et al. (2010) \\
\hline & $\begin{array}{l}\text { NS between Holstein, Jersey, and } \\
\text { Brown Swiss }\end{array}$ & Carroll et al. (2006) & Higher in winter than spring & Rego et al. (2008) \\
\hline & & & $\begin{array}{l}\text { Highest in winter, lowest May to } \\
\text { July }\end{array}$ & Kliem et al. (2013) \\
\hline \multirow[t]{3}{*}{ C18:0 (stearic acid) } & NS between Minhota and HF & Ramalho et al. (2012) & Higher in summer & Palladino et al. (2010); \\
\hline & $\begin{array}{l}\text { No difference for DF, MRY, GWH, } \\
\text { and Jersey }\end{array}$ & Maurice-Van Eijndhoven et al. (2011) & $\begin{array}{l}\text { May and August lower than June } \\
\text { when lower content of chicory and } \\
\text { lucerne }\end{array}$ & Larsen et al. (2012) \\
\hline & NS between HF and Jersey & Palladino et al. (2010) & $\begin{array}{l}\text { NS, spring or winter } \\
\text { Highest in June, lowest in October }\end{array}$ & $\begin{array}{l}\text { Rego et al. }(2008) \\
\text { r Kliem et al. }(2013)\end{array}$ \\
\hline
\end{tabular}


Breed

Season

Fatty acid $^{2}$

Effect

Reference

Effect

Reference

Odd-chain SFA

C13:0

C15:0

C17:0

Branched-chain FA

C13:0 iso

C14:0 iso

$\mathrm{C} 15: 0$ iso

C15:0 anteiso

C16:0 iso

C17:0 iso

C17:0 anteiso

Unsaturated FA

C14:1 cis-9 (myristoleic acid)

C16:1 cis-9 (palmitoleic acid)

C18:1 trans-9 (elaidic acid)

C18:1 trans-10

C18:1 trans-11 (vaccenic acid)

C18:1 cis-9 (oleic acid)

C18:2 cis-9,12 (linoleic acid)

C18:2 cis-9,trans-11 (CLA)
NS between Holstein, Jersey, and Carroll et al. (2006) Brown Swiss

Minhota higher than HF

HF higher than Jersey

Pamalho et al. (2012)

Setween Holstein. Jersey, and Calladino et al. (2010)

Brown Swiss

NS between Holstein, Jersey, and Carroll et al. (2006)

Brown Swiss

Minhota higher than HF

NS between Minhota and HF

Ramalho et al. (2012) Ramalho et al. (2012) Ramalho et al. (2012)

NS between Holstein and Jersey

NS between Minhota and HF

HF higher than Jersey

Holstein higher than Jersey

Minhota higher than HF

NS between Holstein, Jersey, and

Brown Swiss

NS between Holstein and Jersey Higher in Holstein than Brown Swiss

Croissant et al. (2007) Ramalho et al. (2012) Palladino et al. (2010) Croissant et al. (2007) Ramalho et al. (2012)

Carroll et al. (2006)

Palladino et al. (2010) Carroll et al. (2006)

Holstein higher than Jersey

Croissant et al. (2007)

HF higher than Jersey

Palladino et al. (2010)

Higher in Brown Swiss than Jersey Carroll et al. (2006) and Holstein

Holstein higher than Jersey

Croissant et al. (2007) NS between Holstein and Jersey

Palladino et al. (2010)

NS between Holstein, Jersey, and Carroll et al. (2006) Brown Swiss

HF higher than Jersey Palladino et al. (2010)

NS between Holstein, Jersey, and Carroll et al. (2006)

Brown Swiss
Lower in summer

Lower in summer

Higher in spring than winte

Higher in summer

NS

Higher in spring than winter

Lower in summer

Higher in spring than winter Higher in spring than winter

NS, spring or winter

NS, spring or winter

Higher in spring than winter

Higher in winter

Higher in winter than spring Higher in winter

Higher in winter than spring

NS spring or winter

NS

Palladino et al. (2010)

Total trans 18:1 highest Aug/Sep/ Dunshea et al. (2008)

Higher in spring than winter

Higher in summer

NS

Higher in winter than spring

Rego et al. (2008)

Lowest in May/lowest content of Larsen et al. (2012)

chicory and lucerne

Higher in summer

Higher in summer

Highest in May/highest

concentration of red clover

Higher in summer

NS

Total cis/trans 18:2 highest

Aug/Sep/Oct

Higher in spring than winter

Higher in summer
Rego et al. (2008) Revello Chion et al. (2010)

Palladino et al. (2010)

Palladino et al. (2010)

Palladino et al. (2010)

Revello Chion et al. (2010)

Palladino et al. (2010)

Palladino et al. (2010)

Rego et al. (2008)

Rego et al. (2008)

et al. (2008)

Revello Chion et al. (2010)

Rego et al. (2008)

Revello Chion et al. (2010)

(2008)

Palladino et al. (2010)

Larsen et al. (2012)

Revello Chion et al. (2010)

Palladino et al. (2010)

Dunshea et al. (2008)

Rego et al. (2008)

Revello Chion et al. (2010
Revello Chion et al. (2010) 
vaccenic acid (VA) and CLA (C18:2 cis-9,trans-11). Similar variations between breeds for milk fat concentration and composition were observed by Ramalho et al. (2012) and Carroll et al. (2006). Soyeurt et al. (2007) analyzed data from 7,700 milk samples, from 25 herds, representing 7 cow breeds including HolsteinFriesian and Jersey. They observed that heritabilities for milk yield, milk protein, and fat percentages were 18,28 , and $32 \%$, respectively. In addition, $20 \%$ of the variability seen in milk fat composition, especially for the most abundant FA in milk, was caused by genetics. A summary of studies comparing milk FA composition from different breeds is listed in Table 3. For most conventional dairy farms, the effect of breed on milk composition might be considered negligible because Holstein is the dominant breed for dairying; however, strain and genetic merit affect milk composition and performance under specific farming systems differently (Auldist et al., 2000; Nauta et al., 2009). Organic dairy farmers prefer non-Holstein and mixed breeds, and generalizations are, therefore, less appropriate (Nauta et al., 2006; Honorato et al., 2014).

Individual $\mathrm{FA}$ in cow milk derive from different sources (e.g., diet, rumen, and mammary gland). A better understanding of the origin of FA may help to explain the variation observed between different milk samples. Even-chain SFA with chain lengths from C4 to $\mathrm{C} 16$ are produced de novo in the mammary gland from acetic and butyric acids (Lindmark Månsson, 2008). Odd- and branched-chain FA (OBCFA) are synthesized by ruminal bacteria and influenced indirectly by the diet, whereas long-chain FA (including C16:0) and PUFA originate directly from feed. A large proportion of PUFA is biohydrogenated in the rumen, with up to $99 \%$ of ALA partially or completely hydrogenated (Leiber et al., 2005). Conversely, a large proportion of FA are desaturated in the mammary gland by $\Delta^{9}$-desaturase (Vlaeminck et al., 2006). The long-chain PUFA eicosapentaenoic acid (EPA) and docosahexaenoic acid (DHA) are converted endogenously from ALA in the mammary gland but the conversion rate is low (Tu et al., 2010). Small amounts of FA in milk can be derived from adipose tissue of the animal. This occurs predominantly when the animal is in negative energy balance and can be observed as an increased concentration of oleic acid (C18:1 cis-9) in milk (Gross et al., 2011; Loften et al., 2014).

\section{Milk Protein Content}

Protein concentration and composition in milk are largely unresponsive to variations in nutrition and management (Walker et al., 2004), whereas individual cow genetics, stage of lactation, and breed significantly 
Table 4. Effect of different forages on individual milk fatty acids

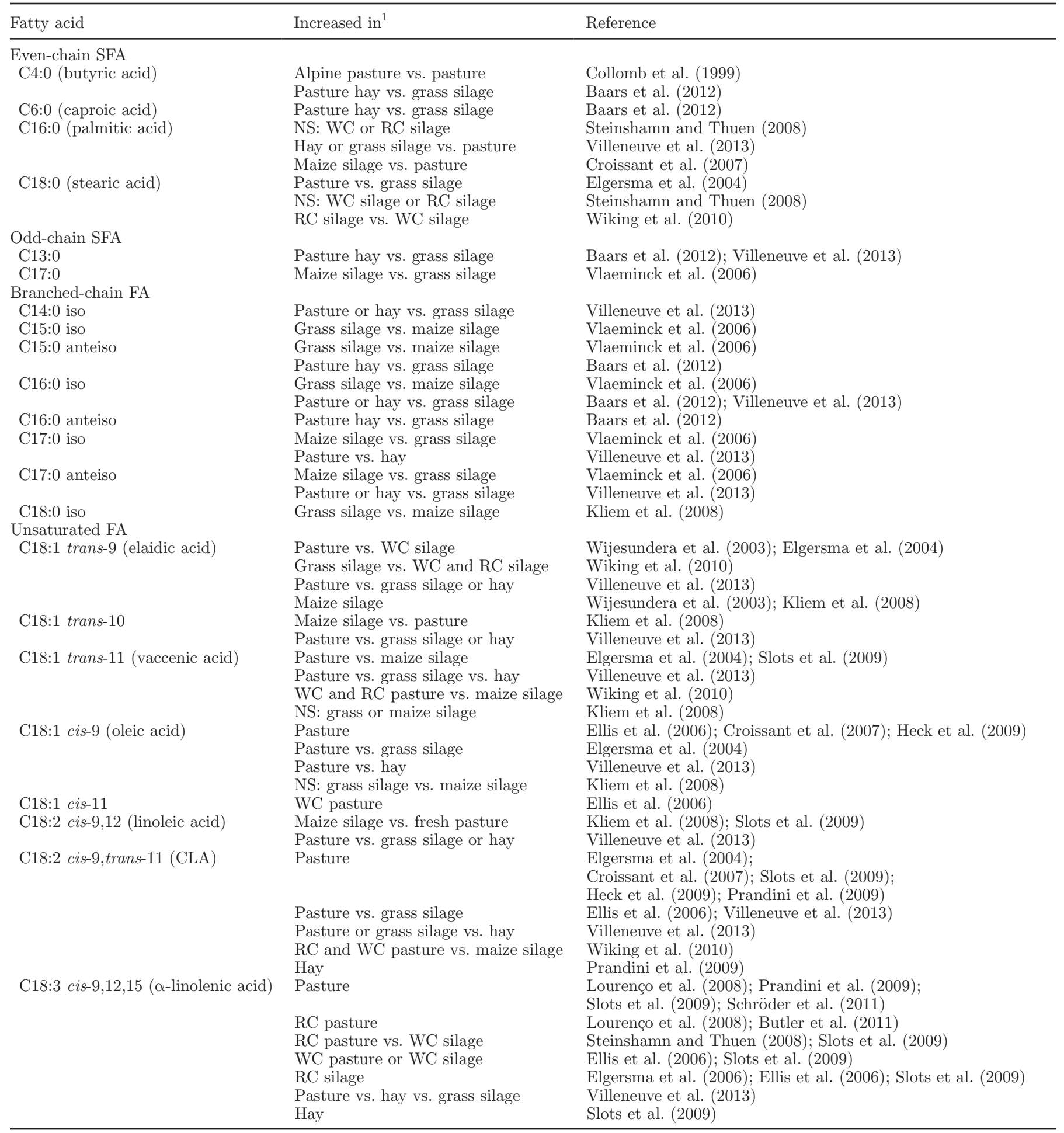

\footnotetext{
${ }^{1} \mathrm{WC}=$ white clover; $\mathrm{RC}=$ red clover.
}

affect the concentration of protein in milk (MauriceVan Eijndhoven et al., 2011). Increased amounts of protein in conventional milk were observed by Bilik and Lopuszanska-Rusek (2010) and Kuczyńska et al. (2012), as well as in trials conducted by Hanus et al. (2008b) and Sundberg et al. (2010). Müller and Sauerwein (2010) reported a tendency for conventional milk to contain a higher concentration of protein. In contrast, 
Table 5. Differences in milk composition between organic and conventional produced milk

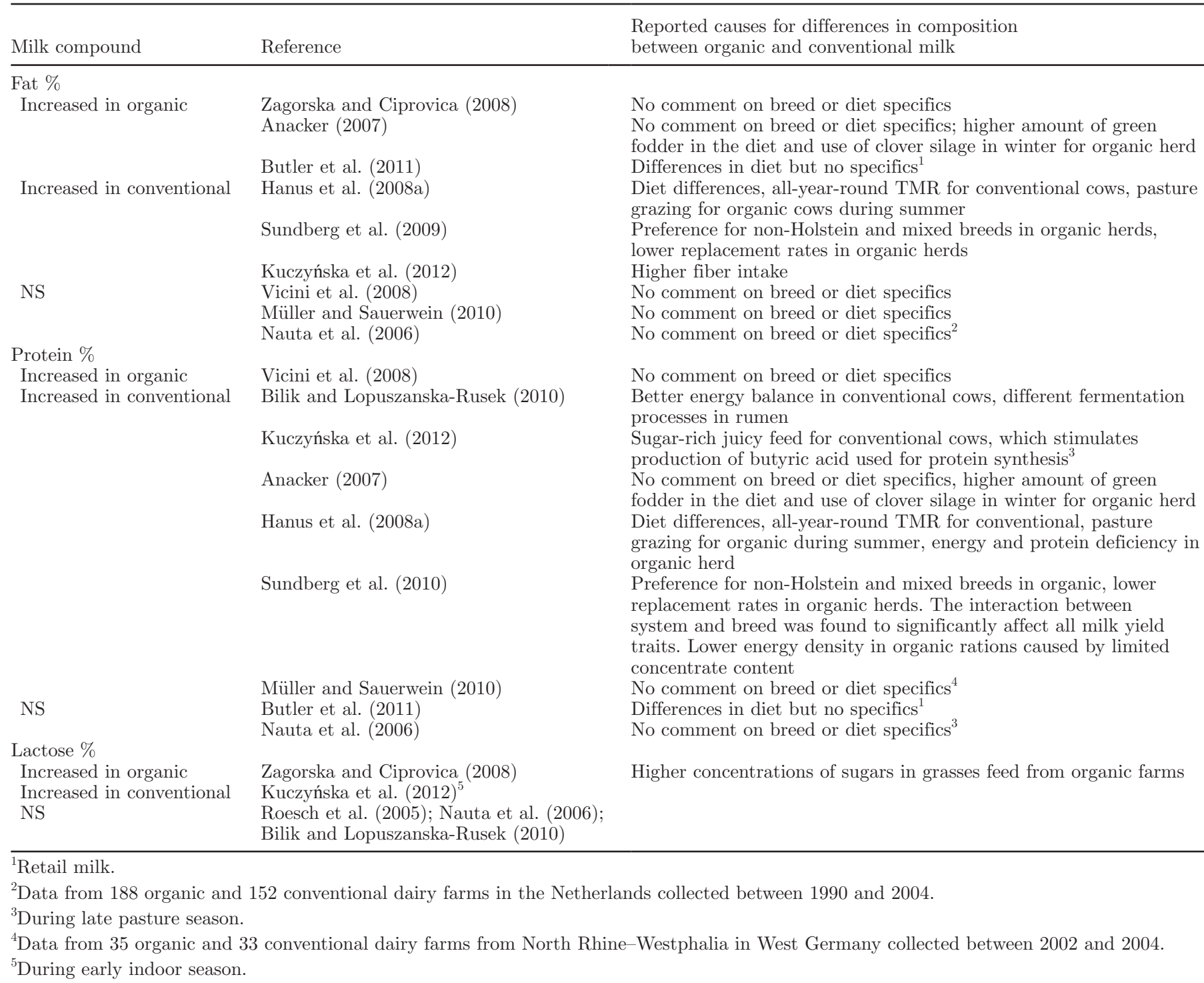

Vicini et al. (2008) reported significantly increased protein concentration in organic milk, compared with conventional and recombinant bST-free milk (3.22 vs. 3.14 vs. $3.15 \%$ protein, respectively). Anacker (2007) similarly observed higher protein concentrations in organic milk during monthly recordings on 2 conventional and 1 organic farm over a 2 -yr period (3.39 vs. $3.20 \% ; P$ $<0.001$ ) in organic and conventional milk, respectively. Milk protein concentration is positively correlated with ME and, to a lesser extent, MP intake. Dietary starch and CP interaction affects milk and protein yield and concentration (Cabrita et al., 2007). Consequently, supplementation with starch-based concentrates can increase the rate of protein synthesis in the mammary gland (Rius et al., 2010). Organic farming regulations limit the use of supplements; therefore, lower protein concentrations could be expected in milk from organic farms. Higher protein concentrations in milk can be expected in herds with New Zealand Friesian as the dominant breed, compared with US Holstein cows on a similar diet (Auldist et al., 2000). Different types of forage or grains and fertilizer application rate can also affect milk protein concentration. Moorby et al. (2009) observed a decrease in milk protein concentration when red clover silage was replaced with ryegrass silage, whereas Vanhatalo et al. (2006) reported a reduction in milk protein concentration when feeding oats rather than barley. Lower concentrations of milk protein have been reported when higher amounts of $\mathrm{N}$ fertilizer $(240$ $\mathrm{kg}$ of $\mathrm{N} /$ ha compared with none, and 150 compared with $25 \mathrm{~kg}$ of $\mathrm{N} / \mathrm{ha}$ ) were applied (Hermansen et al., 1994; Mackle et al., 1996). Consequently, differences in intensification of grassland cultivation can affect milk protein concentration. 
Table 6. Ratio of n-6:n-3 FA and PUFA:SFA in organic (Org) and conventional (Conv) retail milk from different countries

\begin{tabular}{|c|c|c|c|c|c|}
\hline \multirow[b]{2}{*}{ Country } & \multicolumn{2}{|c|}{ n-6:n-3 } & \multicolumn{2}{|c|}{ PUFA:SFA } & \multirow[b]{2}{*}{ Reference } \\
\hline & Org & Conv & Org & Conv & \\
\hline Denmark & 4 & 8 & - & - & Slots et al. (2008) \\
\hline Sweden & 1.88 & 2.11 & 0.06 & 0.05 & Fall and Emanuelson (2011) \\
\hline Switzerland & 1.37 & 1.61 & 0.08 & 0.08 & Collomb et al. (2008) \\
\hline United Kingdom & 1.51 & 2.54 & 0.06 & 0.05 & Ellis et al. (2006) \\
\hline United Kingdom & 2.63 & 3.76 & 0.05 & 0.04 & Butler et al. (2011) \\
\hline United States & 3.24 & 7.12 & 0.06 & 0.08 & O'Donnell et al. (2010) \\
\hline United States & 2.28 & 5.77 & 0.05 & 0.06 & Benbrook et al. (2013) \\
\hline
\end{tabular}

\section{Milk Lactose Content}

Lactose, the major carbohydrate of milk, maintains the osmolarity of milk and is positively correlated with milk volume (Shahbazkia et al., 2010). Mechanisms and biology of lactose synthesis and regulation are the subject of ongoing research (Jenkins and McGuire, 2006). The concentrations of the 2 proteins making up lactose synthase, $\alpha$-lactalbumin and $\beta 1$,4-galactosyltransferase, are positively correlated with milk protein, fat, and lactose concentrations, and stage of lactation (Bleck et al., 2009). The interaction of dietary starch and CP can affect lactose concentration and yield (Rius et al., 2010). Nevertheless, changes in lactose concentration caused by dietary changes are less common and occur only in extreme circumstances (Jenkins and McGuire, 2006). Studies on human milk showed no relationship between lactose concentration and maternal nutrition (Lönnerdal et al., 1976; Emmett and Rogers, 1997). Lemosquet et al. (2009) found no link between wholebody glucose rate of appearance and milk lactose yield in dairy cows after duodenal infusion of glucose. Similarly, the level of MP in the diet reportedly has no effect on milk lactose percentage (Wang et al., 2007). Stage of lactation (Walker et al., 2004) and SCC (Forsbäck et al., 2010) affected the lactose content in milk, whereas no difference in concentration of lactose was detected between Holstein, Jersey, Brown Swiss, and Ayrshire breeds (Bleck et al., 2009). Several publications reported no significant difference in lactose contents between organic and conventionally produced milk (Roesch et al., 2005; Nauta et al., 2006; Bilik and Lopuszanska-Rusek, 2010); however, Kuczyńska et al. (2012) observed differences in lactose concentration between the 2 milk varieties after cows transitioned to an indoor diet. No cause for this change was suggested. Zagorska and Ciprovica (2008) reported variation in lactose concentration between systems and suggested that differences in diets were a possible cause.

\section{Summary of Main Components}

Results reported for milk yield and fat, protein, and lactose concentrations are inconclusive if considered solely from the point of view of organic versus conventional. Seemingly contradicting results (as listed in Table 5) can be expected when individual trial results are not put into context. Factors that influence milk fat and protein concentrations need to be considered before drawing conclusions on whether organic and conventional milks are different in their chemical composition. Individual trials need to report basic information on cow breed and diet, along with any additional factors that could be responsible for reported results (e.g., age, SCC, stage of lactation, and fertilizer application). Unfortunately, many authors fail to provide any indication of diet or breed used in their trials, although both factors are well known to influence milk composition (Toledo et al., 2002). Sundberg et al. (2010) demonstrated that interactions between system and breed were significant and affected all milk production traits, including milk fat and protein yields, whereas Cabrita et al. (2007) observed significant interactions between dietary starch and CP that affected milk, protein, and lactose yields and protein and lactose concentrations. It is rather difficult, therefore, to reach a conclusion about differences between organic and conventionally produced milk for the main milk components if these factors are unknown.

\section{CONVENTIONAL VERSUS ORGANIC MILK: FATTY ACIDS}

\section{Milk from Retail and Dairy Plants}

Fatty acids are the most widely studied components when comparing organic and conventional milk, with a considerable amount of research focusing on FA composition. For this review, studies that analyzed milk 
Table 7. Fatty acid composition of organic and conventional retail milk

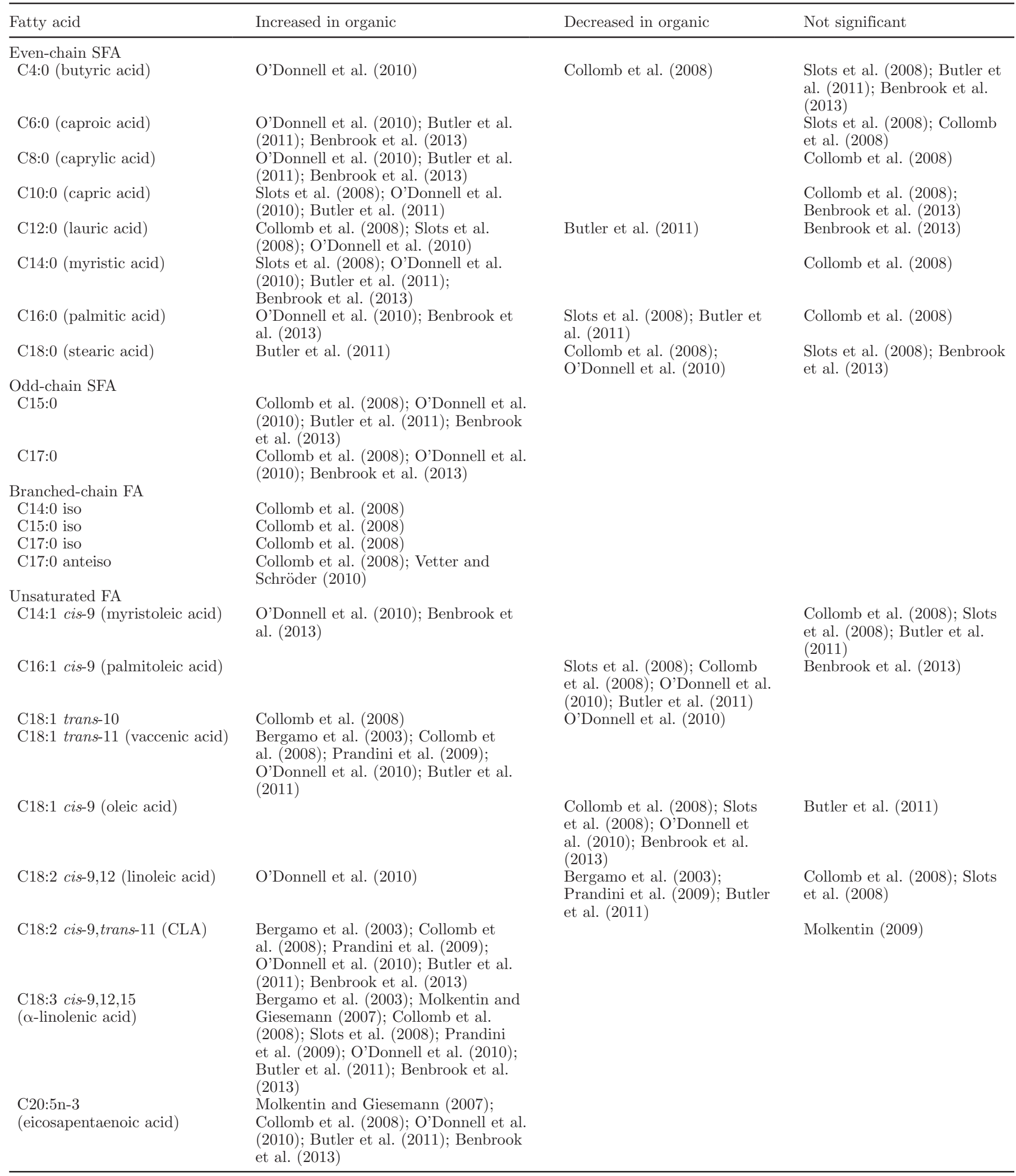




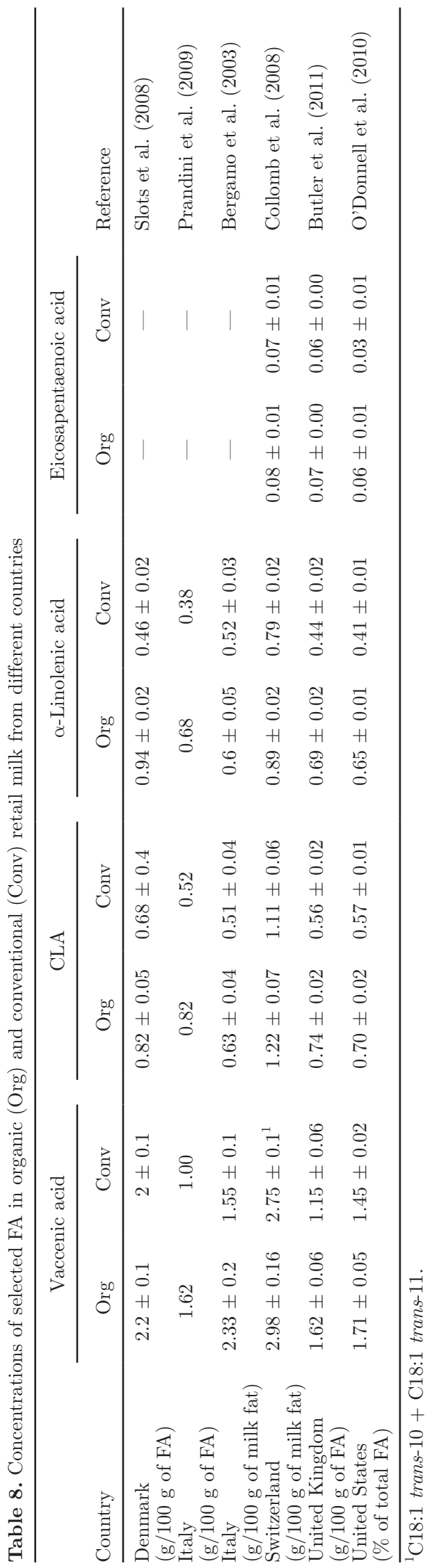

samples from retail outlets and dairy plants were considered separately from those that observed individual farms or animals. Retail samples represent a mixture of milk from a wide variety of individual cows and farms. This consequently "dilutes" the effect of each individual cow and of specific farm practices (Table 6). Extremes are, therefore, less significant (e.g., genetics, health, parity and stage of lactation from individual cows; farm specifics in diet, breed, drenching, and fertilizer application). Nevertheless, regulations (e.g., food standards and subsidies), geographical features (e.g., climate and altitude), and regional characteristics (e.g., local breeds and agricultural practices) affect milk FA composition independent of the individual farm and the effects of diet and cow breed used in a specific region. Kliem et al. (2013) analyzed conventional milk samples purchased monthly from 5 retail outlets in an 8 -km radius in the United Kingdom between November 2008 and October 2009. Significant differences in the FA profiles between the supermarkets were observed and explained by the different pools of milk suppliers, which likely originated from different geographical areas (Kliem et al., 2013). Not surprisingly, the comparison of several studies on organic and conventional retail milk, as listed in Table 6 , showed inconsistent results for most even-chain SFA. Therefore, no conclusions can be drawn as to whether a specific FA is more likely to be increased or decreased in the 2 milk varieties (organic or conventional). Results for OBCFA display greater agreement, but the number of studies considering these is limited. Results for MUFA and PUFA show greater consistency, and higher concentrations of VA, CLA, ALA, and EPA in organic milk have been reported independently of the country of origin (United States, United Kingdom, Denmark, Germany, Switzerland, and Italy), sampling season (January to December), and year (2003 to 2011). This result might suggest, that independent of origin, organic cows consume a different diet (higher amount of pasture and other forages) than conventional cows. This can be seen as a direct result of regulations mandating that organic dairy cows in the United States and European countries (Department for Environment, Food and Rural Affairs, 2010) have access to pasture and outdoor areas.

Some studies have suggested that n-3 and CLA FA impart health benefits to the consumer (Givens, 2005; Nagpal et al., 2007). One could therefore conclude that organic retail milk may be advantageous for human consumption. However, the comparison of actual amounts of individual FA (Table 7) and the ratios of n-6:n-3 FA (Table 8) showed large variation between countries and supports the claim from Schönfeldt et al. (2012) for country-specific milk data. Ratios of PUFA and SFA are similar by comparison, with only Collomb et al. (2008) reporting significantly higher values 
than the other studies. This can be explained by the specific study conditions in the mountainous area of Switzerland, which relied on a high-forage diet for both organic and conventional cows. Kuczynska et al. (2011) reported similar high PUFA:SFA ratios for cows on a high-forage diet during the summer season.

Causes for the different trends of individual FA (e.g., SFA) between studies are variable but are largely influenced by country and regional characteristics. O'Donnell et al. (2010) reported higher amounts for all SFA in organic retail milk, except for C18:0 in the United States during October and November 2006. Benbrook et al. (2013) investigated milk FA composition in retail milk with monthly collections from January 2011 to July 2012 in the United States. The results for all FA match those from O'Donnell et al. (2010), but no significant difference between the milk varieties was observed for C4:0, C10:0, and C18:0. The study from O'Donnell et al. (2010) was undertaken before USDA organic standards came into effect in 2010, which mandated that organic cows have access to pasture for $120 \mathrm{~d} / \mathrm{yr}$ and consume $30 \%$ of their DMI from pasture while grazing. The change in milk FA between the 2 American studies (O'Donnell et al., 2010; Benbrook et al, 2013) might be an effect of the change in standards, but the significant difference in study length also needs to be considered. Butler et al. (2011) reported that samples collected in England between August 2006 and January 2008 had lower amounts of C12:0 and C16:0 in organic milk but no significant difference between the 2 milk varieties for C4:0. The UK register of Organic Food Standards (UKROFS) states that herbivores should have a DMI consisting of at least $60 \%$ roughage, fresh or dried fodder, or silage. This difference in standards might explain the difference in FA composition between organic and conventional milk in the United States and United Kingdom. Organic and conventional bulk tank milk from 3 dairies in Switzerland showed no significant difference for SMCFA, except for C12:0, which was increased in organic milk, and C4:0, which was higher in conventional milk (Collomb et al., 2008). Slots et al. (2008) sampled milk from Danish dairy plants and observed that SMCFA were either increased in organic milk or not significantly different between the 2 milk types, with C16:0 being the exception. Collomb et al. (2008) reported that although diets between organic and conventional cows were not identical, both groups obtained more than $80 \%$ of their DMI from grass (fresh grass, grass silage, or hay), which might explain why no differences for most SMCFA were found. This diet differs significantly from the United States and United Kingdom standards.

Apart from variances in forage type, amount, and quality, differences in breeds or strains in the studies mentioned above are potential contributors to the differences in milk FA profile reported between and within organic and conventional milk samples. It is impossible to determine the actual effect of the cow breed in the presented studies, but their effect cannot be excluded. Collomb et al. (2008) reported Brown Swiss, Swiss Fleckvieh, Simmental, and Red Holstein to be the dominant breeds in the Swiss trial, whereas the study from Butler et al. (2011) in the United Kingdom excluded milk from minority breeds. Breed was not mentioned by Slots et al. (2008) or O'Donnell et al. (2010). Therefore, we can only assume that the circumstances in which these studies were undertaken reflect conditions expected of these countries. Holstein is the dominant breed in the United Kingdom, United States, and Denmark, representing 95, 90, and $72 \%$ of all dairy cows, respectively (Nygaard, 2007; Department for Environment, Food and Rural Affairs, 2010), but there is a trend toward non-Holstein breeds on organic dairy farms (Roderick and Burke, 2004; Sundberg et al., 2010; Benbrook et al., 2013). We can assume that the percentage of Holstein cows in the dairy herd varies between countries, as well as between organic and conventional farm systems; consequently, this will influence the FA composition in milk.

\section{Milk from Research Units and Dairy Farms}

Studies researching the difference between organic and conventional milk samples from a limited number of animals and dairy farms are constrained in their ability to conclude whether the 2 milk varieties differ in general. Depending on the number of farms and animals involved, these studies need to take more factors into account (e.g., animal genetic, individual management, specific herd characteristics, and microclimate), to avoid conclusions based on inter-herd or inter-animal variation (Hou, 2011) rather than the farming system (organic or conventional). The benefit of these studies lies in their ability to measure and control influencing factors and, consequently, characterize their effects. Adler et al. (2013), for example, compared milk samples from 28 organic and conventionally managed farms and was able to explain the differences between the 2 milk varieties in terms of pasture composition, FA profile in concentrate, and seasonal variations. Differences in FA profile between organic and conventional milk (among others) were found for C18:0, C18:1 cis-9, ALA, EPA, and DHA. Concentrations of $\mathrm{C} 18: 0$ and $\mathrm{C} 18: 1$ cis-9 were increased in concentrate feed for conventional cows, which was reflected in conventional milk. The same was seen for ALA in organic concentrate feed and reflected in organic milk. Higher amounts of EPA and DHA in organic milk are explained by the use of fish 
oil supplementation for organic cows. Other studies are less conclusive in their reporting of (possible) causes for their results. Butler et al. (2008) investigated 25 commercial farms during the grazing period and classified them into high-input $(\mathbf{H I})$ conventional, low-input (LI) organic, and LI conventional farms. Low-input organic and conventional showed no significant differences for VA, ALA, total SFA, MUFA, PUFA, or n-6:n-3 ratio. For conventional HI farms, total SFA content was increased, whereas total MUFA, PUFA, VA, ALA, and CLA contents in milk were decreased compared with milk from LI farms. This difference in concentrations was even more pronounced for conventional LI farms than for organic LI farms. The differences between HI and LI farms in milk FA profile and the similarity between the 2 LI systems can be explained by the diet, with both LI systems having more than $80 \%$ of their diets as fresh forage compared with less than $40 \%$ for the HI farm. In Butler et al. (2008), LI organic cows had a larger part of their diet as conserved forages and concentrates compared with LI conventional, which might explain the significantly higher CLA concentration for LI conventional milk. A possible cause for the higher proportion of fresh forage in the LI conventional diet might be related to the application of phosphate and nitrogen fertilizer on the LI conventional farm, which might have resulted in higher DM yield compared with the same area on organic LI farms. Anacker (2007) studied 1 organic and 2 conventional farms for consecutive years on a monthly basis and reported higher amounts of C18:0, LA, CLA, ALA, and n-3 FA in organic milk, whereas no significant difference was observed for C18:1 cis-9 or SFA between organic and conventional milks. No dietary specifics were given to explain these results, but organic cows had access to green fodder and a maximum of $40 \%$ concentrate in their diet. Furthermore, no chemical fertilizer or pesticides were used on the organic farm. The higher amounts of ALA and PUFA in organic milk could be explained by the assumption of higher forage intake for organic compared with conventional cows. Higher values for $\mathrm{n}-3 \mathrm{FA}$ and CLA $(P=0.067)$ in organic bulk milk samples were also found by Bloksma et al. (2008), who reported a higher intake of pasture and clover silage for organic cows, whereas conventional cows consumed more concentrate and maize silage. Jahreis et al. (1997) observed significantly greater amounts of CLA in milk from organic and conventional farms with pasture access in summer and a silage-rich diet in winter compared with milk from conventional cows kept indoors and fed cereal and maize silage. This was explained by the higher amount of PUFA in fresh pasture, leading to an increase in VA and CLA. Higher amounts of CLA in milk from organic cows compared with forage (including pasture)-fed conventional cows were explained by the differences in silage used during the winter period. Organic cows consumed grass and clover silages, which are rich in PUFA compared with maize silage. It was also suggested that organic pastures and silages contained a higher amount of crude fiber, which could have influenced the composition of the rumen microbiota (Jahreis et al., 1997). Ellis et al. (2006) observed no significant difference between milk varieties for CLA overall. This was explained by the extended sample set of 36 farms, resulting in a wider variation of CLA concentrations within farm systems than in other studies, with individual farm factors having a significant influence on CLA concentration. Molkentin and Giesemann (2007) similarly reported a large deviation in ALA concentration in organic milk, caused by the larger variety of feed used, compared with conventional farm management. Pasture grazing led to a significantly increased CLA concentration in milk compared with silage and TMR feeding. Ellis et al. (2006) also demonstrated that pasture feeding, a preference for mixed-breed herds, and herds with lower milk yields are factors that significantly increased n-3 FA concentrations in milk. Consequently, several factors and their interactions have to be considered before evaluating the difference between organic and conventional milk.

\section{CONVENTIONAL VERSUS ORGANIC MILK: MINOR COMPONENTS}

\section{Vitamins and Antioxidants}

Milk contains water and fat-soluble vitamins, and several research studies have investigated whether the concentrations of these essential nutrients differ between organic and conventionally produced milk. Several studies focused on vitamin A, its precursor $\beta$-carotene, and $\alpha$-tocopherol, a form of vitamin $\mathrm{E}$. As antioxidants, they are of interest to milk processors because they may prevent spontaneous oxidized flavor in milk. A higher amount of PUFA, as commonly associated with organic milk, and the resulting greater risk of oxidation makes it desirable to have a greater quantity of antioxidants present in organic milk. The contents of $\alpha$-tocopherol and $\beta$-carotene in milk depend on the contents in the diet (Swensson and Lindmark-Mansson, 2007; Mogensen et al., 2012). The highest concentration of vitamins ( $\alpha$-tocopherol and $\beta$-carotene) can be found in fresh forage. The loss of vitamins occurs during wilting, ensiling, and storage, affecting different crops (e.g., rye grass, clover, and maize) differently (Kalač, 2011; Blank et al., 2013). Conserved or dried forages and cereals are considered a 
poorer source of $\alpha$-tocopherol and $\beta$-carotene compared with fresh forage (Kay et al., 2005). However, results on whether milk derived from a diet rich in fresh forages (commonly organic) contains more $\beta$-carotene and $\alpha$-tocopherol than milk from animals consuming larger amounts of concentrates (commonly conventional) are inconsistent, as concentrates can be supplemented with vitamins. Butler et al. (2008) reported higher amounts of $\alpha$-tocopherol and $\beta$-carotene in bulk milk samples from organic and LI conventional farms compared with milk from HI conventional farms. Higher concentrations of $\alpha$-tocopherol and $\beta$-carotene in organic milk were also reported by Bergamo et al. (2003) and Slots et al. (2008). Slots et al. (2008) observed that the overall difference in $\alpha$-tocopherol concentration between the 2 milk varieties was less significant $(P<0.023)$ than that for individual stereoisomers. The natural stereoisomer $R R R \quad \alpha$-tocopherol was significantly higher in organic milk, whereas the synthetic $2 R$ stereoisomer of $\alpha$-tocopherol was significantly higher in conventional milk $(P<0.001)$. Similar results were described by Butler et al. (2008) who reported significantly higher amounts of $R R R$-tocopherol in LI organic and LI conventional milk compared with HI conventional milk, with no significant difference for the synthetic $2 R$ stereoisomer observed between the 3 milk varieties. The study indicates that synthetic antioxidants can be present in organic milk and that conventional milk can have similar high concentrations of $\alpha$-tocopherol, caused by the fortification of concentrates. Significant differences were also reported for the amount of carotenoids (including $\beta$-carotene), with the highest and lowest concentrations observed in LI conventional and HI conventional milks, respectively. The difference in antioxidant concentration between LI organic and LI conventional milk might be related to the difference in fresh forage intake (Butler et al., 2008). No significant difference in $\alpha$-tocopherol and $\beta$-carotene levels in organic and conventional milk was found by Ellis et al. (2007b), whereas vitamin A was found to be higher in conventional milk. They observed that concentrate feeding was positively correlated with vitamin A, $\alpha$-tocopherol, and $\beta$-carotene concentrations in milk, with individual farm effects sampling month and milk yield as additional influencing factors. Similarly, no significant difference between organic and conventional milk for $\beta$-carotene and $\alpha$-tocopherol was found by Fall and Emanuelson (2011), who compared organic and conventional dairy herds during winter. Lack of fresh pasture for organic cows and therefore a similarity in diet between the herds was given as an explanation for these results. Zagorska and Ciprovica (2008) reported on the concentration of the water-soluble vitamins thiamine and riboflavin $\left(\mathrm{B}_{1}\right.$ and $\left.\mathrm{B}_{2}\right)$ in milk. Samples were taken from 5 organic and conventional farms in Latvia, with significantly lower concentrations $(P<0.05)$ for both vitamins observed in organic milk samples. Both vitamins are found in cereals (Powers, 2003; Gołda et al., 2004), and an increased amount in conventional milk could be explained by a higher intake of grains in the diet of conventional dairy cows. All studies demonstrate that feed composition rather than farming system (organic vs. conventional) influence concentration of vitamins (and their precursors) in milk.

\section{Minerals}

Several research studies have compared the mineral contents of organic and conventional milk. Individual minerals have to be considered separately because they might be beneficial for animals and humans or considered contaminants. Mineral content in milk is, depending on the element, influenced by individual cow genetics (van Hulzen et al., 2009), farm management, and surrounding environment (Gabryszuk et al., 2008). Factors that influence soil and pasture mineral composition include fertilizer application (McKenzie and Jacobs, 2002), disposal of sewage sludge (Percival, 2003), soil type (Mut et al., 2009), and proximity to mining areas (Smith et al., 2009), industrial activities (Gabryszuk et al., 2008), or automotive emissions (Ward et al., 1977).

Calcium and Magnesium. Concentrations of $\mathrm{Ca}$ and $\mathrm{Mg}$ in milk are highly heritable and only marginally influenced by diet (van Hulzen et al., 2009). Calcium in milk is associated with casein, which remains relatively constant in milk during dietary changes of the animal (Haug et al., 2007). Higher concentrations of both Ca and $\mathrm{Mg}$, as well as P, can be found in breeds with higher casein and phospholipid concentrations (e.g., Jersey vs. Holstein; Hermansen et al., 2005). The concentrations of $\mathrm{Ca}$ and $\mathrm{Mg}$ increase with stage of lactation from increased degradation of $\alpha_{\mathrm{S}}$-casein due to $\mathrm{pH}$ changes (Sapru et al., 1997; Coulon et al., 1998). Although not discussed by Gabryszuk et al. (2008), stage of lactation might have contributed to higher concentrations of $\mathrm{Ca}$ $(P<0.01)$ and $\mathrm{Mg}(P<0.05)$ in milk from HI conventional (lactation average $162 \mathrm{~d}$ ), and LI organic cows (lactation average 193 and 173 d), compared with LI conventional cows (lactation average $117 \mathrm{~d}$ ). Čuboň et al. (2008) reported higher Ca levels in bulk organic milk but found no difference in the total protein concentration between organic and conventional milk. The bulk milk samples in this study originated from 1 organic and 1 conventional herd of similar size and breed (Slovac Prinzgau), located in the same geographical area with morning and evening milks sampled over several months (May to February). No explanation for differ- 
ences in Ca concentration was given, but minimum protein concentrations were reported in different months in organic (August) and conventional (May) milks. This might indicate differences in casein concentration and potential differences in stage of lactation between the farms. The use of $\mathrm{Na}$ fertilizer or $\mathrm{Na}$ supplements can also increase the $\mathrm{Ca}$ and $\mathrm{Mg}$ status in bovine milk while decreasing the SCC (Phillips et al., 2000).

Iodine and Selenium. Contents of I and Se in organic and conventional milks have been extensively researched, with both elements being essential for animal and human health. The concentration of both elements in milk greatly depends on dietary intake, and dairy cows have been supplemented with I for decades to prevent deficiencies (Bath et al., 2012). Iodine is readily taken up from the diet and introduced into milk, with milk produced by concentrate-fed cows showing higher I levels than milk from cows grazing pasture (Gabryszuk et al., 2008). In countries with winter housing, concentrations of I in milk are largely influenced by season and the subsequent change in diet, with levels decreasing in summer (Haug et al., 2007). A study of retail milk in the United Kingdom showed that although there were regional variations in I levels, conventional retail milk contained up to $42 \%$ more I than organic milk (Bath et al., 2012). Similar results have been reported in studies from Germany (Johner et al., 2012), Norway (Dahl et al., 2003), and Spain (ReyCrespo et al., 2013). For all studies, I concentration was significantly lower in organic milk, a difference that was even more pronounced during summer season when pasture feeding increases. Use of iodophor sanitizers for teats and equipment could additionally contribute to I levels in milk, and might explain the variability in I concentrations observed in conventional milk (Bath et al., 2012; Rey-Crespo et al., 2013). Selenium is also an essential mineral, and ruminants are susceptible to Se deficiency caused by a lack of absorption from the diet (van Hulzen et al., 2009). This is especially prevalent in animals fed high amounts of pasture rather than silage or TMR (Gabryszuk et al., 2008). Pilarczyk et al. (2011) found that in areas of low soil Se levels, conventional cows fed diets based on hay, cereals, and pasture had significantly lower Se levels in milk than cows feeding on TMR. Selenium content in milk from organic cows that consumed a diet high in hay and maize silage was significantly higher $(P<0.001)$ than that of conventional cows with access to pasture (Pilarczyk et al., 2011). Fall and Emanuelson (2011) could not establish any differences between Se levels in milk of organic and conventional cows in Sweden during winter, however, citing the similarity in diets as an explanation.

Heavy Metals. Concentrations of heavy metals in bovine milk have been a research objective in many countries (Licata et al., 2004; Qin et al., 2009; Abdulkhaliq et al., 2012), with the research focus being predominantly related to concerns for human health. Environment and diet are the main factors influencing concentrations of metals in milk, with different breeds affected differently (Hermansen et al., 2005) and correlations between elements observed (Pilarczyk et al., 2013). Anacker (2007) reported that although no difference was observed between organic and conventional milk, the concentrations of $\mathrm{As}, \mathrm{Cd}, \mathrm{Cu}$, and $\mathrm{Hg}$ changed significantly between years. The main source for heavy metals (e.g., As, $\mathrm{Cd}, \mathrm{Hg}$, and $\mathrm{Pb}$ ) in agricultural systems is fertilizer (Gray et al., 2003; Mirlean et al., 2008). Differences in fertilizer application and pasture growth rate might explain the variation in heavy metal concentrations for different years reported by Anacker (2007). No differences and generally very low concentrations for $\mathrm{Cd}$ and $\mathrm{Pb}$ were observed by Ghidini et al. (2005), who compared organic and conventionally produced milk and meat in Italy. Comparable results for $\mathrm{Cd}, \mathrm{Cu}, \mathrm{Fe}$, and $\mathrm{Zn}$ concentrations in organic and conventional bulk milk were found by Zagorska and Ciprovica (2005), who analyzed samples from different regions of Latvia. Hanus et al. (2008a) reported elevated $\mathrm{Cu}$ levels in conventional milk in a comparative study of organic and conventional farms in the Czech Republic. Similarly, Rey-Crespo et al. (2013) observed higher concentrations of $\mathrm{Cu}$, Se, and $\mathrm{Zn}$ in conventional milk on the farm and retail levels compared with organic farm milk, which was explained with the high supplementation rate of these essential elements in concentrate feed.

\section{Hormones}

Milk and dairy products naturally contain estrogens (Malekinejad et al., 2006) and the possible effect on human health has been of research interest (Daxenberger et al., 2001). Estrone $\left(\mathrm{E}_{1}\right)$ and estradiol $\left(\alpha \mathrm{E}_{2}\right.$ and $\left.\beta \mathrm{E}_{2}\right)$ concentrations in bovine milk are positively correlated with stage of gestation in the animal. Estrogen concentrations in retail milk vary depending on the milk fat percentage, which can be explained by the lipophilic character of these hormones (Pape-Zambito et al., 2010). No significant difference in estrone concentration between organic and conventional milk was detected. The concentration of estradiol $\left(\beta \mathrm{E}_{2}\right)$ in organic milk increased at a greater rate with an increase in fat compared with conventional milk. Although these differences were significant, they were not considered biologically relevant. A higher fat percentage in organic milk than indicated on the label might have been the cause for the reported difference (Pape-Zambito et al., 2010). Vicini et al. (2008) analyzed estradiol and progesterone 
concentrations in organic and conventional retail milk from 48 states within the United States collected over 3 wk. They reported higher levels of both hormones in organic milk $(P<0.05)$ and explained these differences by potentially lower feed intake of organic cows, and differences in average gestation state between organic and conventional cows.

\section{CONVENTIONAL VERSUS ORGANIC MILK: OTHER ASPECTS}

\section{Udder Health and SCC}

Management issues such as milking hygiene and cow cleanliness (Ellis et al., 2007a) influence the incidence of udder infection, which can affect milk yield and composition. Milk protein and fat yields and percentages can be negatively correlated with a high SCC (Juozaitiene et al., 2004; Ogola et al., 2007; Guo et al., 2010). Consequently, conclusions on compositional differences between organic and conventionally produced milk should be made after taking into account udder health. The SCC of organic and conventional milk has been compared in a range of published studies, most of which reported no significant difference between the milk types (Muller and Lehmann, 2007; Müller and Sauerwein, 2010; Mullen et al., 2013; Stiglbauer et al., 2013). Sundberg et al. (2009) studied records of 471 organic herds and almost 14,000 conventional herds from 1998 to 2005 in Sweden, and found no differences in SCC at a given production level. Others reported lower SCC in organic milk (Ellis et al., 2007a; Cuboň et al., 2008; Garmo et al., 2010). Roesch et al. (2007) found higher median SCC in organic milk $31 \mathrm{~d}$ postpartum and similar SCC for organic and conventional herds at 102 d postpartum. Similarly, cases of subclinical and clinical mastitis were not different between organic and conventional cows (Sundberg et al., 2009). Vaarst and Bennedsgaard (2001) analyzed incidences of mastitis treatments for 27 organic and 57 conventional herds in Denmark. The farming system (organic vs. conventional) appeared to have less influence on udder health compared with management factors (e.g., routine teat dipping). Valle et al. (2007) reported that differences in health handling (e.g., seeking veterinary treatment) rather than differences in actual animal health between organic and conventional cows may influence mastitis statistics. No differences in animal health between farming types were found, with the exception of a lower incidence of clinical mastitis in organic farms, which was thought to be due in part to the lower milk production of organic cows (Valle et al., 2007). Richert et al. (2013) noted that farming intensity rather than system (organic vs. conventional) influenced the frequency of veterinary visits. Ahlman et al. (2011) reported a higher culling rate due to poor udder health for organic cows compared with conventional cows, when studying 402 organic and 5,335 conventional herds between 1998 and 2003. Ahlman et al. (2011) observed, similar to Valle et al. (2007), that culling reasons might not depend solely on udder health status but on the priorities and tolerance levels of individual farmers. A generalization on whether or not organic farmers have a lower tolerance for poor udder health is not possible because ethical considerations may differ and regulations regarding the use of antibiotics as treatment option for organic cows do differ between countries (Mullen et al., 2013).

\section{Flavor and Taste}

Organic milk is associated not only with the image of being safe and environmentally friendly, but also with being more flavorful than conventional milk (Managi et al., 2008; Liu et al., 2013). Flavor differences have been studied in milk from cows fed different amounts of concentrate and pasture (Croissant et al., 2007; Bloksma et al., 2008; Bovolenta et al., 2009), with no difference in consumer acceptance reported. Similarly, no obvious difference in taste was established when comparing organic and conventional milk but trials found organic milk to be creamier and with greater intensity of grassy flavor (Bloksma et al., 2008). Consumption temperature of milk ( 7 vs. $15^{\circ} \mathrm{C}$ ) affected the intensity of specific flavors (Croissant et al., 2007), which can be explained by the increased volatility of flavor compounds with higher temperatures. Cmen et al. (2010) suggested that a lower concentration of fat in organic milk in spring was related to a loss in flavor, whereas Coggins et al. (2008) reported that trained panelists were not able to differentiate between plain yogurts of different fat contents or milk varieties (organic vs. conventional). Gallina Toschi et al. (2012) similarly observed that consumers did not distinguish between odor and taste of yogurt produced from organic and conventional milks but noted that the most-liked conventional yogurt scored higher when it was labeled as organic.

\section{Identification}

Partly due to the demand of premium prices for organic milk in a growing retail market, researchers have investigated factors to identify or distinguish organic from conventional milk. Several molecular markers have been considered in regard to their significantly different concentrations in organic and conventional milk. The supposed difference in concentration relates back to a significant difference in diet between organic and conventional cows. To date, all suggested markers have 
failed when organic and conventional diets were similar (e.g., in LI organic and LI conventional farms). Phytanic acid, for example, which is converted from phytol released from chlorophyll, can be used as an indicator of the amount of green fodder in the diet of a dairy cow (Vetter and Schröder, 2010; Schröder et al., 2011). Therefore, phytanic acid could be used to identify organic milk, with the limitation that comparisons could only be made between milk from conventional cows that had limited access to green fodder and milk from organic cows mainly fed forage. The same limitations were found for ALA as a marker molecule (Molkentin, 2009). Organic milk generally contains higher amounts of ALA, caused by greater amounts of fresh forage in the diet, but Flowers et al. (2008) showed that supplementation with $5 \%$ linseed oil doubled the levels of ALA in conventional milk, thereby matching the values observed in organic milk. The method described by Molkentin, (2008) determines the carbon stable isotope ratio $\left(\delta^{13} \mathrm{C}\right)$ in milk. The method is based on the fact that maize (which is commonly used in concentrate feed for conventional cows) is a $\mathrm{C}_{4}$ plant (compared with other common feed plants), which uses a different biosynthetic pathway to fixate atmospheric $\mathrm{CO}_{2}$. This leads to a stronger accumulation of the ${ }^{13} \mathrm{C}$ isotope in the plant, which can be detected in milk. The method would therefore enable determination of the amount of maize in the diet of the animal. The limitations of this method are related to the need for a difference in maize concentration between organic and conventional diets, and to the inability to establish whether the maize was produced organic or conventionally. A characterization of organic and conventionally produced milk using metabolomics has been applied by Boudonck et al. (2009). Hippurate, proline, ribose 5-phosphate, and carnitine were among the 14 identified metabolites significantly different between organic and conventional whole-milk brands. Whether or not these differences are caused by differences in diet or metabolic pathways in the animals needs to be established. Hippuric acid was considered as a marker molecule but was found to be unsuitable because its content depended on the feeding regimen rather than the production system (Boudonck et al., 2009; Carpio et al., 2010). Capuano et al. (2014) examined the feasibility of distinguishing between milk samples from cows with or without pasture access via Fourier transform infrared spectroscopy. However, as in other studies, classification of a sample as organic or conventional had to be considered more cautiously and general conclusions could not be made. All current approaches described in the literature depend on a significant difference between diets that either results in a measurable change in the amount of a certain marker molecule or in a characteristic alteration of an isotope ratio in milk. As such, these methods are not able to differentiate between intensive organic and extensive conventional farming systems.

\section{CONCLUSIONS}

Numerous factors affect milk composition, and knowledge about their interactions is limited. The same can be said about the large number of studies comparing organic and conventional milk and the limited number of generally accepted research conclusions on the differences between organic and conventionally produced milk. This limitation arises for 2 reasons, the first of which is the lack of comparable conditions within and between trials. In general, most researchers have not controlled sufficient variables to allow a valid comparison between organic and conventionally produced cow milk. Diet composition and breed of cow are the minimum factors that need to be considered and reported when aiming to compare milk samples. The second reason is that current regulations for organic milk production do not allow for a distinct separation from conventionally produced milk. In other words, no "organic effect" exists that can be credited to a holistic combination of factors affected by the organic system. If animal genetics, health, breed, diet, management, or environment differs, then so will the composition of the milk produced.

\section{ACKNOWLEDGMENTS}

This work was funded by grants from Fonterra Cooperative Group Limited (New Zealand), Ministry of Science and Innovation (New Zealand), and AGMARDT (New Zealand).

\section{REFERENCES}

Abdulkhaliq, A., K. M. Swaileh, R. M. Hussein, and M. Matani. 2012. Levels of metals $(\mathrm{Cd}, \mathrm{Pb}, \mathrm{Cu}$ and $\mathrm{Fe})$ in cow's milk, dairy products and hen's eggs from the West Bank, Palestine. Int. Food Res. J. 19:1089-1094.

Abrahamse, P. A., J. Dijkstra, B. Vlaeminck, and S. Tamminga. 2008. Frequent allocation of rotationally grazed dairy cows changes grazing behavior and improves productivity. J. Dairy Sci. 91:20332045 .

Adler, S. A., S. K. Jensen, E. Govasmark, and H. Steinshamn. 2013. Effect of short-term versus long-term grassland management and seasonal variation in organic and conventional dairy farming on the composition of bulk tank milk. J. Dairy Sci. 96:5793-5810.

Ahlman, T., B. Berglund, L. Rydhmer, and E. Strandberg. 2011. Culling reasons in organic and conventional dairy herds and genotype by environment interaction for longevity. J. Dairy Sci. 94:15681575. http://dx.doi.org/10.3168/jds.2010-3483.

Anacker, G. 2007. Differences between composition of organic milk and conventional milk. Lebensmitt. Milchwirtsch. 128:17-25.

Arnold, C., and G. Jahreis. 2011. Milk fat and health. Ernahrungs Umschau 58:177-181.

AsureQuality. 2013. AsureQuality Organic Standard For Primary Producers - Version 5. Page 129. AsureQuality Ltd., New Zealand. 
Auldist, M. J., and I. B. Hubble. 1998. Effects of mastitis on raw milk and dairy products. Aust. J. Dairy Technol. 53:28-36.

Auldist, M. J., A. R. Napper, and E. S. Kolver. 2000. Contribution of nutrition to seasonal variation of milk composition in New Zealand Friesian and US Holstein dairy cows. Asian-australas. J. Anim. Sci. 13:513-515.

Baars, T., J. Wohlers, D. Kusche, and G. Jahreis. 2012. Experimental improvement of cow milk fatty acid composition in organic winter diets. J. Sci. Food Agric. http://dx.doi.org/10.1002/jsfa.5525.

Ballou, L. U., M. Pasquini, R. D. Bremel, T. Everson, and D. Sommer. 1995. Factors affecting herd milk composition and milk plasmin at four levels of somatic cell counts. J. Dairy Sci. 78:2186-2195.

Bartl, K., C. A. Gomez, M. García, T. Aufdermauer, M. Kreuzer, H. D. Hess, and H. R. Wettstein. 2008. Milk fatty acid profile of Peruvian Criollo and Brown Swiss cows in response to different diet qualities fed at low and high altitude. Arch. Anim. Nutr. 62:468-484. http://dx.doi.org/10.1080/17450390802453450.

Bath, S. C., S. Button, and M. P. Rayman. 2012. Iodine concentration of organic and conventional milk: Implications for iodine intake. Br. J. Nutr. 107:935-940. http://dx.doi.org/10.1017/ S0007114511003059.

Benbrook, C. M., G. Butler, M. A. Latif, C. Leifert, and D. R. Davis. 2013. Organic production enhances milk nutritional quality by shifting fatty acid composition: A United States-wide, 18-month study. PLoS ONE 8:e82429. http://dx.doi.org/10.1371/journal. pone.0082429.

Bergamo, P., E. Fedele, L. Iannibelli, and G. Marzillo. 2003. Fat-soluble vitamin contents and fatty acid composition in organic and conventional Italian dairy products. Food Chem. 82:625-631. http://dx.doi.org/10.1016/s0308-8146(03)00036-0.

Bilal, G., R. I. Cue, A. F. Mustafa, and J. F. Hayes. 2012. Short communication: Estimates of heritabilities and genetic correlations among milk fatty acid unsaturation indices in Canadian Holsteins. J. Dairy Sci. 95:7367-7371. http://dx.doi.org/10.3168/jds.20125684 .

Bilik, K., and M. Lopuszanska-Rusek. 2010. Effect of organic and conventional feeding of Red-and-White cows on productivity and milk composition. Ann. Anim. Sci. 10:441-458.

Blank, B., D. Schaub, H. M. Paulsen, and G. Rahmann. 2013. Comparison of performance and feeding parameters in organic and conventional dairy farms in Germany. Landbauforschung Volkenrode 63:21-27. (In German)

Bleck, G. T., M. B. Wheeler, L. B. Hansen, H. Chester-Jones, and D. J. Miller. 2009. Lactose synthase components in milk: Concentrations of $\alpha$-lactalbumin and $\beta 1,4$-galactosyltransferase in milk of cows from several breeds at various stages of lactation. Reprod. Domest. Anim. 44:241-247.

Bloksma, J., R. Adriaansen-Tennekes, M. Huber, L. P. L. van de Vijver, T. Baars, and J. de Wit. 2008. Comparison of organic and conventional raw milk quality in The Netherlands. Biol. Agric. Hortic. 26:69-83.

Boudonck, K. J., M. W. Mitchell, J. Wulff, and J. A. Ryals. 2009. Characterization of the biochemical variability of bovine milk using metabolomics. Metabolomics 5:375-386. http://dx.doi. org/10.1007/s11306-009-0160-8.

Bovolenta, S., M. Corazzin, E. Saccà, F. Gasperi, F. Biasioli, and W. Ventura. 2009. Performance and cheese quality of Brown cows grazing on mountain pasture fed two different levels of supplementation. Livest. Sci. 124:58-65. http://dx.doi.org/10.1016/j. livsci.2008.12.009.

Butler, G., J. H. Nielsen, M. K. Larsen, B. Rehberger, S. Stergiadis, A. Canever, and C. Leifert. 2011. The effects of dairy management and processing on quality characteristics of milk and dairy products. NJAS Wageningen. J. Life Sci. 58:97-102. http://dx.doi. org/10.1016/j.njas.2011.04.002.

Butler, G., J. H. Nielsen, T. Slots, C. Seal, M. D. Eyre, R. Sanderson, and C. Leifert. 2008. Fatty acid and fat-soluble antioxidant concentrations in milk from high- and low-input conventional and organic systems: Seasonal variation. J. Sci. Food Agric. 88:14311441. http://dx.doi.org/10.1002/jsfa.3235.
Cabrita, A. R. J., R. J. B. Bessa, S. P. Alves, R. J. Dewhurst, and A. J. M. Fonseca. 2007. Effects of dietary protein and starch on intake, milk production, and milk fatty acid profiles of dairy cows fed corn silage-based diets. J. Dairy Sci. 90:1429-1439.

Canadian General Standards Board. 2011. Organic Production Systems General Principles and Management Standards. Page 39. Standards Council of Canada.

Capuano, E., J. Rademaker, H. van den Bijgaart, and S. M. van Ruth. 2014. Verification of fresh grass feeding, pasture grazing and organic farming by FTIR spectroscopy analysis of bovine milk. Food Res. Int. 60:59-65. http://dx.doi.org/10.1016/j.foodres.2013.12.024.

Carpio, A., V. Rodríguez-Estévez, M. Sánchez-Rodríguez, L. Arce, and M. Valcárcel. 2010. Differentiation of organic goat's milk based on its hippuric acid content as determined by capillary electrophoresis. Electrophoresis 31:2211-2217.

Carroll, S. M., E. J. DePeters, S. J. Taylor, M. Rosenberg, H. Perez-Monti, and V. A. Capps. 2006. Milk composition of Holstein, Jersey, and Brown Swiss cows in response to increasing levels of dietary fat. Anim. Feed Sci. Technol. 131:451-473.

Cmen, M., N. Yldrm, A. Dkc, O. Kaplan, and N. C. Yldrm. 2010. Seasonal variations of biochemical taste parameters in milks from conventional and environment-friendly organic farming. Bulg. J. Agric. Sci. 16: 728-732.

Coggins, P. C., M. W. Schilling, S. Kumari, and P. D. Gerrard. 2008. Development of a sensory lexicon for conventional milk yogurt in the United States. J. Sens. Stud. 23:671-687. http://dx.doi. org/10.1111/j.1745-459X.2008.00179.x.

Coleman, J., K. M. Pierce, D. P. Berry, A. Brennan, and B. Horan. 2010. Increasing milk solids production across lactation through genetic selection and intensive pasture-based feed system. J. Dairy Sci. 93:4302-4317. http://dx.doi.org/10.3168/jds.2009-2591.

Collomb, M., W. Bisig, U. Buetikofer, R. Sieber, M. Bregy, and L. Etter. 2008. Fatty acid composition of mountain milk from Switzerland: Comparison of organic and integrated farming systems. Int. Dairy J. 18:976-982.

Collomb, M., U. Bütikofer, M. Spahni, B. Jeangros, and J. O. Bosset. 1999. Fatty acid and glyceride composition of cow's milk fat in high-and lowland regions. Sci. Aliments 19:97-110.

Coppa, M., A. Ferlay, C. Chassaing, C. Agabriel, F. Glasser, Y. Chilliard, G. Borreani, R. Barcarolo, T. Baars, D. Kusche, O. M. Harstad, J. Verbič, J. Golecký, and B. Martin. 2013. Prediction of bulk milk fatty acid composition based on farming practices collected through on-farm surveys. J. Dairy Sci. 96:4197-4211. http://dx.doi.org/10.3168/jds.2012-6379.

Coulon, J. B., I. Verdier, P. Pradel, and M. Almena. 1998. Effect of lactation stage on the cheesemaking properties of milk and the quality of Saint-Nectaire-type cheese. J. Dairy Res. 65:295-305.

Craninx, M., A. Steen, H. Van Laar, T. Van Nespen, J. Martin-Tereso, B. De Baets, and V. Fievez. 2008. Effect of lactation stage on the odd- and branched-chain milk fatty acids of dairy cattle under grazing and indoor conditions. J. Dairy Sci. 91:2662-2677. http://dx.doi.org/10.3168/jds.2007-0656.

Croissant, A. E., S. P. Washburn, L. L. Dean, and M. A. Drake. 2007. Chemical properties and consumer perception of fluid milk from conventional and pasture-based production systems. J. Dairy Sci. 90:4942-4953.

Čuboň, J., V. Foltys, P. Haščík, M. Kačániová, I. Ubrežiová, S. Kráčmar, and K. Vavrišínová. 2008. The raw milk quality from organic and conventional agriculture. Acta Univ. Agric. Silvic. Mendel. Brun. 56:25-30.

Dahl, L., J. A. Opsahl, H. M. Meltzer, and K. Julshamn. 2003. Iodine concentration in Norwegian milk and dairy products. Br. J. Nutr. 90:679-685. http://dx.doi.org/10.1079/bjn2003921.

Dangour, A. D., K. Lock, A. Hayter, A. Aikenhead, E. Allen, and R. Uauy. 2010. Nutrition-related health effects of organic foods: A systematic review. Am. J. Clin. Nutr. 92:203-210. http://dx.doi. org/10.3945/ajcn.2010.29269.

Daxenberger, A., D. Ibarreta, and H. H. D. Meyer. 2001. Possible health impact of animal oestrogens in food. Hum. Reprod. Update 7:340-355. http://dx.doi.org/10.1093/humupd/7.3.340. 
Department for Environment, Food and Rural Affairs. 2010. Guidance Document on European Union Organic Standards. Page 31. Welsh Assembly Government; Department of Agriculture and Rural Development; The Scottish Government.

Department for Environment, Food and Rural Affairs. 2011. The Cattle Book 2008. Descriptive Statistics of Cattle Numbers in Great Britain on June 2008. Defra, London, UK.

Dunshea, F. R., G. P. Walker, E. Ostrowska, and P. T. Doyle. 2008. Seasonal variation in the concentrations of conjugated linoleic and trans fatty acids in milk fat from commercial dairy farms is associated with pasture and grazing management and supplementary feeding practices. Aust. J. Exp. Agric. 48:1062-1075. http:// dx.doi.org/10.1071/ea0728610.1071/EA99132.

Elgersma, A., G. Ellen, H. Van Der Horst, H. Boer, P. R. Dekker, and S. Tamminga. 2004. Quick changes in milk fat composition from cows after transition from fresh grass to a silage diet. Anim. Feed Sci. Technol. 117:13-27. http://dx.doi.org/10.1016/j.anifeedsci.2004.08.003.

Elgersma, A., S. Tamminga, and G. Ellen. 2006. Modifying milk composition through forage. Anim. Feed Sci. Technol. 131:207-225. http://dx.doi.org/10.1016/j.anifeedsci.2006.06.012.

Ellis, K. A., G. Innocent, D. Grove-White, P. Cripps, W. G. McLean, C. V. Howard, and M. Mihm. 2006. Comparing the fatty acid composition of organic and conventional milk. J. Dairy Sci. 89:19381950.

Ellis, K. A., G. T. Innocent, M. Mihm, P. Cripps, W. G. McLean, C. V. Howard, and D. Grove-White. 2007a. Dairy cow cleanliness and milk quality on organic and conventional farms in the UK. J. Dairy Res. 74:302-310. http://dx.doi.org/10.1017/S002202990700249X.

Ellis, K. A., A. Monteiro, G. T. Innocent, D. Grove-White, P. Cripps, W. Graham McLean, C. V. Howard, and M. Mihm. 2007b. Investigation of the vitamins $\mathrm{A}$ and $\mathrm{E}$ and $\beta$-carotene content in milk from UK organic and conventional dairy farms. J. Dairy Res. 74:484-491. http://dx.doi.org/10.1017/S0022029907002816.

Emmett, P. M., and I. S. Rogers. 1997. Properties of human milk and their relationship with maternal nutrition. Early Hum. Dev. 49:S7-S28. http://dx.doi.org/10.1016/s0378-3782(97)00051-0.

Fall, N., and U. Emanuelson. 2011. Fatty acid content, vitamins and selenium in bulk tank milk from organic and conventional Swedish dairy herds during the indoor season. J. Dairy Res. 78:287-292. http://dx.doi.org/10.1017/S0022029911000392.

Ferlay, A., C. Agabriel, C. Sibra, C. Journal, B. Martin, and Y. Chilliard. 2008. Tanker milk variability in fatty acids according to farm feeding and husbandry practices in a French semi-mountain area. Dairy Sci. Technol 88:193-215. http://dx.doi.org/10.1051/ dst:2007013.

Flowers, G., S. A. Ibrahim, and A. A. AbuGhazaleh. 2008. Milk fatty acid composition of grazing dairy cows when supplemented with linseed oil. J. Dairy Sci. 91:722-730. http://dx.doi.org/10.3168/ jds.2007-0410.

Forman, J., J. Silverstein, J. J. S. Bhatia, S. A. Abrams, M. R. Corkins, S. D. De Ferranti, N. H. Golden, J. A. Paulson, A. C. BrockUtne, H. L. Brumberg, C. C. Campbell, B. P. Lanphear, K. C. Osterhoudt, M. T. Sandel, L. Trasande, and R. O. Wright. 2012. Organic foods: Health and environmental advantages and disadvantages. Pediatrics 130:e1406-e1415. http://dx.doi.org/10.1542/ peds.2012-2579.

Forsbäck, L., H. Lindmark-Månsson, A. Andrén, M. Åkerstedt, L. Andrée, and K. Svennersten-Sjaunja. 2010. Day-to-day variation in milk yield and milk composition at the udder-quarter level. J. Dairy Sci. 93:3569-3577.

Gabryszuk, M., K. Słoniewski, and T. Sakowski. 2008. Macro- and microelements in milk and hair of cows from conventional vs. organic farms. Anim. Sci. Pap. Rep. 26:199-209.

Gallina Toschi, T., A. Bendini, S. Barbieri, E. Valli, M. L. Cezanne, K. Buchecker, and M. Canavari. 2012. Organic and conventional nonflavored yogurts from the Italian market: Study on sensory profiles and consumer acceptability. J. Sci. Food Agric. 92:2788-2795. http://dx.doi.org/10.1002/jsfa.5666.

Garmo, R. T., S. Waage, S. Sviland, B. I. F. Henriksen, O. Østerås, and O. Reksen. 2010. Reproductive performance, udder health, and antibiotic resistance in mastitis bacteria isolated from Norwegian Red cows in conventional and organic farming. Acta Vet. Scand. 52: http://dx.doi.org/10.1186/1751-0147-52-11.

Ghidini, S., E. Zanardi, A. Battaglia, G. Varisco, E. Ferretti, G. Campanini, and R. Chizzolini. 2005. Comparison of contaminant and residue levels in organic and conventional milk and meat products from Northern Italy. Food Addit. Contam. 22:9-14. http:// dx.doi.org/10.1080/02652030400027995.

Givens, D. I. 2005. The role of animal nutrition in improving the nutritive value of animal-derived foods in relation to chronic disease. Proc. Nutr. Soc. 64:395-402. http://dx.doi.org/10.1079/ pns2005448.

Gołda, A., P. Szyniarowski, K. Ostrowska, A. Kozik, and M. RapałaKozik. 2004. Thiamine binding and metabolism in germinating seeds of selected cereals and legumes. Plant Physiol. Biochem. 42:187-195.

Gray, C. W., R. G. McLaren, and A. H. C. Roberts. 2003. Cadmium leaching from some New Zealand pasture soils. Eur. J. Soil Sci 54:159-166. http://dx.doi.org/10.1046/j.1365-2389.2003.00495.x.

Gross, J., H. A. Van Dorland, R. M. Bruckmaier, and F. J. Schwarz. 2011. Milk fatty acid profile related to energy balance in dairy cows. J. Dairy Res. 78:479-488. http://dx.doi.org/10.1017/ S0022029911000550.

Gruber, L., R. Steinwender, T. Guggenberger, J. Häusler, and A. Schauer. 2001. Comparison of organic and conventional farming on a grassland farm. Second Communication: Feed intake, milk yield, health and fertility parameters. Bodenkultur 52:55-70.

Guéguen, L., and G. Pascal. 2010. An update on the nutritional and health value of organic foods. Cahiers de Nutrition et de Dietetique 45:130-143. http://dx.doi.org/10.1016/j.cnd.2010.02.002.

Guo, J. Z., X. L. Liu, A. J. Xu, and Z. Xia. 2010. Relationship of somatic cell count with milk yield and composition in Chinese Holstein population. Agric. Sci. China 9:1492-1496.

Hanus, O., J. Brychtova, V. Gencurova, J. Pesl, I. Hulova, M. Vyletelova, R. Jedelska, and J. Kopecky. 2008a. Effect of conversion from conventional to organic dairy farm on milk quality and health of dairy cows. Folia Vet. 52:140-148.

Hanus, O., Z. Vorlicek, K. Sojkova, R. Rozsypal, M. Vyletelova, P. Roubal, V. Gencurova, J. Pozdisek, and H. Landova. 2008b. A comparison of selected milk indicators in organic herds with conventional herd as reference. Folia Vet. 52:155-159.

Haug, A., A. T. Hostmark, and O. M. Harstad. 2007. Bovine milk in human nutrition-A review. Lipids Health Disease 6:25. http:// dx.doi.org/10.1186/1476-511x-6-25.

Heck, J. M. L., H. J. F. van Valenberg, J. Dijkstra, and A. C. M. van Hooijdonk. 2009. Seasonal variation in the Dutch bovine raw milk composition. J. Dairy Sci. 92:4745-4755. http://dx.doi. org/10.3168/jds.2009-2146.

Hermansen, J. E., J. H. Badsberg, T. Kristensen, and V. Gundersen. 2005. Major and trace elements in organically or conventionally produced milk. J. Dairy Res. 72:362-368. http://dx.doi. org/10.1017/S0022029905000968.

Hermansen, J. E., S. Ostersen, and O. Aaes. 1994. Effect of the levels of $\mathrm{N}$ fertilizer, grass and supplementary feeds on nitrogen composition and renneting properties of milk from cows at pasture. J. Dairy Res. 61:179-189.

Honorato, L. A., L. C. P. Machado Filho, I. D. Barbosa Silveira, and M. J. Hötzel. 2014. Strategies used by dairy family farmers in the south of Brazil to comply with organic regulations. J. Dairy Sci. 97:1319-1327. http://dx.doi.org/10.3168/jds.2012-6532.

Hou, J. 2011. Variations of trans octadecenoic acids, especially trans-10 C18:1 and trans-11 C18:1 in milk fat. Milchwissenschaft 66:189-192.

Jahreis, G., J. Pritsche, and H. Steinhart. 1997. Conjugated linoleic acid in milk fat: High variation depending on production system. Nutr. Res. 17:1479-1484. http://dx.doi.org/10.1016/s02715317(97)00138-3

Jenkins, T. C., and M. A. McGuire. 2006. Major advances in nutrition: Impact on milk composition. J. Dairy Sci. 89:1302-1310.

Johner, S. A., K. v. Nida, G. Jahreis, and T. Remer. 2012. Time trends and seasonal variation of iodine content in German cows' 
milk-Investigations from North Rhine-Westfalia. Berl. Munch. Tierarztl. Wochenschr. 125:76-82.

Juozaitiene, V., A. Zakas, and A. Juozaitis. 2004. Relationship of somatic cell count with milk yield and composition in the herds of Black-and-White cattle. Med. Weter. 60:701-704.

Kalač, P. 2011. The effects of silage feeding on some sensory and health attributes of cow's milk: A review. Food Chem. 125:307317. http://dx.doi.org/10.1016/j.foodchem.2010.08.077.

Kay, J. K., J. R. Roche, E. S. Kolver, N. A. Thomson, and L. H. Baumgard. 2005. A comparison between feeding systems (pasture and TMR) and the effect of vitamin E supplementation on plasma and milk fatty acid profiles in dairy cows. J. Dairy Res. 72:322332. http://dx.doi.org/10.1017/S0022029905000944.

Khiaosa-Ard, R., F. Klevenhusen, C. R. Soliva, M. Kreuzer, and F. Leiber. 2010. Transfer of linoleic and linolenic acid from feed to milk in cows fed isoenergetic diets differing in proportion and origin of concentrates and roughages. J. Dairy Res. 77:331-336. http://dx.doi.org/10.1017/S0022029910000257.

Kliem, K. E., R. Morgan, D. J. Humphries, K. J. Shingfield, and D. I. Givens. 2008. Effect of replacing grass silage with maize silage in the diet on bovine milk fatty acid composition. Animal 2:18501858. http://dx.doi.org/10.1017/s1751731108003078.

Kliem, K. E., K. J. Shingfield, K. M. Livingstone, and D. I. Givens. 2013. Seasonal variation in the fatty acid composition of milk available at retail in the United Kingdom and implications for dietary intake. Food Chem. 141:274-281. http://dx.doi.org/10.1016/j. foodchem.2013.02.116.

Kuczyńska, B., K. Puppel, M. Gołębiewski, E. Metera, T. Sakowski, and K. Słoniewski. 2012. Differences in whey protein content between cow's milk collected in late pasture and early indoor feeding season from conventional and organic farms in Poland. J. Sci. Food Agric. 92:2899-2904. http://dx.doi.org/10.1002/jsfa.5663.

Kuczynska, B., K. Puppel, E. Metera, P. Klis, A. Grodzka, and T. Sakowski. 2011. Fatty acid composition of milk from Brown Swiss and Holstein-Friesian black and white cows kept in a certified organic farm. Annals of Warsaw University of Life Sciences SGGW, Animal Science 49:61-67.

Larsen, M. K., X. C. Fretté, T. Kristensen, J. Eriksen, K. Søegaard, and J. H. Nielsen. 2012. Fatty acid, tocopherol and carotenoid content in herbage and milk affected by sward composition and season of grazing. J. Sci. Food Agric. http://dx.doi.org/10.1002/ jsfa. 5620 .

Larsen, M. K., J. H. Nielsen, G. Butler, C. Leifert, T. Slots, G. H. Kristiansen, and A. H. Gustafsson. 2010. Milk quality as affected by feeding regimens in a country with climatic variation. J. Dairy Sci. 93:2863-2873. http://dx.doi.org/10.3168/jds.2009-2953.

Leiber, F., M. Kreuzer, D. Nigg, H. R. Wettstein, and M. R. L. Scheeder. 2005. A study on the causes for the elevated n-3 fatty acids in cows' milk of alpine origin. Lipids 40:191-202. http://dx.doi. org/10.1007/s11745-005-1375-3.

Lemosquet, S., E. Delamaire, H. Lapierre, J. W. Blum, and J. L. Peyraud. 2009. Effects of glucose, propionic acid, and nonessential amino acids on glucose metabolism and milk yield in Holstein dairy cows. J. Dairy Sci. 92:3244-3257.

Licata, P., D. Trombetta, M. Cristani, F. Giofrè, D. Martino, M. Calò, and F. Naccari. 2004. Levels of "toxic" and "essential" metals in samples of bovine milk from various dairy farms in Calabria, Italy. Environ. Int. 30:1-6. http://dx.doi.org/10.1016/S01604120(03)00139-9.

Lindmark Månsson, H. 2008. Fatty acids in bovine milk fat. Food Nutr. Res. 52. http://dx.doi.org/10.3402/fnr.v52i0.1821.

Liu, Z., C. A. Kanter, K. D. Messer, and H. M. Kaiser. 2013. Identifying significant characteristics of organic milk consumers: A CART analysis of an artefactual field experiment. Appl. Econ. 45:3110-3121.

Lock, A. L., C. L. Preseault, J. E. Rico, K. E. DeLand, and M. S. Allen. 2013. Feeding a C16:0-enriched fat supplement increased the yield of milk fat and improved conversion of feed to milk. J. Dairy Sci. 96:6650-6659. http://dx.doi.org/10.3168/jds.2013-6892.

Loften, J. R., J. G. Linn, J. K. Drackley, T. C. Jenkins, C. G. Soderholm, and A. F. Kertz. 2014. Invited review: Palmitic and stearic acid metabolism in lactating dairy cows. J. Dairy Sci. 97:46614674. http://dx.doi.org/10.3168/jds.2014-7919.

Lönnerdal, B., E. Forsum, M. Gebre Medhin, and L. Hambraeus. 1976. Breast milk composition in Ethiopian and Swedish mothers. II. Lactose, nitrogen, and protein contents. Am. J. Clin. Nutr. 29:1134-1141.

Lourenço, M., G. Van Ranst, B. Vlaeminck, S. De Smet, and V. Fievez. 2008. Influence of different dietary forages on the fatty acid composition of rumen digesta as well as ruminant meat and milk. Anim. Feed Sci. Technol. 145:418-437. http://dx.doi. org/10.1016/j.anifeedsci.2007.05.043.

Macdonald, K. A., G. A. Verkerk, B. S. Thorrold, J. E. Pryce, J. W. Penno, L. R. McNaughton, L. J. Burton, J. A. S. Lancaster, J. H. Williamson, and C. W. Holmes. 2008. A comparison of three strains of Holstein-Friesian grazed on pasture and managed under different feed allowances. J. Dairy Sci. 91:1693-1707. http:// dx.doi.org/10.3168/jds.2007-0441.

Mackle, T. R., C. R. Parr, and A. M. Bryant. 1996. Nitrogen fertiliser effects on milk yield and composition, pasture intake, nitrogen and energy partitioning, and rumen fermentation parameters of dairy cows in early lactation. N.Z. J. Agric. Res. 39:341-356.

Magkos, F., F. Arvaniti, and A. Zampelas. 2003. Organic food: Nutritious food or food for thought? A review of the evidence. Int. J. Food Sci. Nutr. 54:357-371. http://dx.doi. org/10.1080/09637480120092071.

Malekinejad, H., P. Scherpenisse, and A. A. Bergwerff. 2006. Naturally occurring estrogens in processed milk and in raw milk (from gestated cows). J. Agric. Food Chem. 54:9785-9791. http://dx.doi. org/10.1021/jf061972e

Managi, S., Y. Yamamoto, H. Iwamoto, and K. Masuda. 2008. Valuing the influence of underlying attitudes and the demand for organic milk in Japan. Agric. Econ. 39:339-348. http://dx.doi. org/10.1111/j.1574-0862.2008.00337.x.

Maréchal, C. L., R. Thiéry, E. Vautor, and Y. L. Loir. 2011. Mastitis impact on technological properties of milk and quality of milk products-A review. Dairy Sci. Technol. 91:247-282.

Maurice-Van Eijndhoven, M. H. T., S. J. Hiemstra, and M. P. L. Calus. 2011. Short communication: Milk fat composition of 4 cattle breeds in the Netherlands. J. Dairy Sci. 94:1021-1025. http:// dx.doi.org/10.3168/jds.2009-3018.

McKenzie, F. R., and J. L. Jacobs. 2002. Effects of application of nitrogen fertilizer on concentrations of $\mathrm{P}, \mathrm{K}, \mathrm{S}, \mathrm{Ca}, \mathrm{Mg}, \mathrm{Na}, \mathrm{Cl}$, $\mathrm{Mn}, \mathrm{Fe}, \mathrm{Cu}$ and $\mathrm{Zn}$ in perennial ryegrass/white clover pastures in southwestern Victoria, Australia. Grass Forage Sci. 57:48-53.

Miller, L. A.. J. M. Moorby, D. R. Davies, M. O. Humphreys, N. D. Scollan, J. C. MacRae, and M. K. Theodorou. 2001. Increased concentration of water-soluble carbohydrate in perennial ryegrass ( $\mathrm{Lo}$ lium perenne L.): Milk production from late-lactation dairy cows. Grass Forage Sci. 56:383-394. http://dx.doi.org/10.1046/j.13652494.2001.00288.x.

Ministry of Agriculture, Forestry and Fisheries. 2012. Japanese Agricultural Standard for Organic Livestock Products. Notification No. 1608 of the Ministry of Agriculture, Forestry and Fisheries of October 27, 2005. Partial Revision 2012:17.

Mirlean, N., P. Baisch, I. Machado, and E. Shumilin. 2008. Mercury contamination of soil as the result of long-term phosphate fertilizer production. Bull. Environ. Contam. Toxicol. 81:305-308. http:// dx.doi.org/10.1007/s00128-008-9480-z.

Mogensen, L., T. Kristensen, K. Søegaard, S. K. Jensen, and J. Sehested. 2012. Alfa-tocopherol and beta-carotene in roughages and milk in organic dairy herds. Livest. Sci. 145:44-54. http://dx.doi. org/10.1016/j.livsci.2011.12.021.

Molkentin, J. 2008. Laboratory authentication of organic milk. Deutsche Milchwirtschaft 59:873-874.

Molkentin, J. 2009. Authentication of organic milk using ${ }^{13} \mathrm{C}$ and the alpha-linolenic acid content of milk fat. J. Agric. Food Chem. $57: 785-790$.

Molkentin, J., and A. Giesemann. 2007. Differentiation of organically and conventionally produced milk by stable isotope and fatty acid analysis. Anal. Bioanal. Chem. 388:297-305. 
Moorby, J. M., M. R. F. Lee, D. R. Davies, E. J. Kim, G. R. Nute, N. M. Ellis, and N. D. Scollan. 2009. Assessment of dietary ratios of red clover and grass silages on milk production and milk quality in dairy cows. J. Dairy Sci. 92:1148-1160. http://dx.doi. org/10.3168/jds.2008-1771.

Mullen, K. A. E., L. G. Sparks, R. L. Lyman, S. P. Washburn, and K. L. Anderson. 2013. Comparisons of milk quality on North Carolina organic and conventional dairies. J. Dairy Sci. 96:6753-6762. http://dx.doi.org/10.3168/jds.2012-6519.

Muller, U., and I. Lehmann. 2007. Factors influencing animal health and milk quality. Ökologie \& Landbau 142:40-41.

Müller, U., and H. Sauerwein. 2010. A comparison of somatic cell count between organic and conventional dairy cow herds in West Germany stressing dry period related changes. Livest. Sci. 127:30-37. http://dx.doi.org/10.1016/j.livsci.2009.08.003.

Muller-Lindenlauf, M., C. Deittert, and U. Kopke. 2010. Assessment of environmental effects, animal welfare and milk quality among organic dairy farms. Livest. Sci. 128:140-148. http://dx.doi. org/10.1016/j.livsci.2009.11.013.

Mut, H., I. Ayan, Z. Acar, U. Basaran, Ö. Töngel, and O. Asci. 2009. Relationship between soil structure and botanical composition of the flat pastures in coastal region of Samsun province. Asian J. Chem. 21:971-978.

Nagpal, R., H. Yadav, A. K. Puniya, K. Singh, S. Jain, and F. Marotta. 2007. Conjugated linoleic acid: Sources, synthesis and potential health benefits - An overview. Curr. Top. Nutraceut. Res. 5:55-65.

Nantapo, C. T. W., V. Muchenje, and A. Hugo. 2014. Atherogenicity index and health-related fatty acids in different stages of lactation from Friesian, Jersey and Friesian $\times$ Jersey cross cow milk under a pasture-based dairy system. Food Chem. 146:127-133. http:// dx.doi.org/10.1016/j.foodchem.2013.09.009.

Nauta, W. J., T. Baars, H. Saatkamp, D. Weenink, and D. Roep. 2009. Farming strategies in organic dairy farming: Effects on breeding goal and choice of breed. An explorative study. Livest. Sci. 121:187-199. http://dx.doi.org/10.1016/j.livsci.2008.06.011.

Nauta, W. J., R. F. Veerkamp, E. W. Brascamp, and H. Bovenhuis. 2006. Genotype by environment interaction for milk production traits between organic and conventional dairy cattle production in The Netherlands. J. Dairy Sci. 89:2729-2737.

Nygaard, H. 2007. Farming and milk production in Denmark. In 27th European Holstein and Red Holstein Conference, 2007 World Holstein Friesian Federation. Danish Cattle Federation, Danish Agricultural Advisory Centre. Accessed Nov. 27, 2014. http://www. whff.info/info/conferences/ehc2007/02\%20Farming\%20and\%20 milk\%20production\%20in\%20Denmark.pdf.

O'Donnell, A. M., K. P. Spatny, J. L. Vicini, and D. E. Bauman. 2010 Survey of the fatty acid composition of retail milk differing in label claims based on production management practices. J. Dairy Sci. 93:1918-1925. http://dx.doi.org/10.3168/jds.2009-2799.

Ogola, H., A. Shitandi, and J. Nanua. 2007. Effect of mastitis on raw milk compositional quality. J. Vet. Sci. 8:237-242.

Organic Industry Standards and Certification Committee. 2013. National Standard for Organic and Bio-Dynamic Produce - Edition 3.5. Page 74. Department of Agriculture, Australia.

Palladino, R. A., F. Buckley, R. Prendiville, J. J. Murphy, J. Callan, and D. A. Kenny. 2010. A comparison between Holstein-Friesian and Jersey dairy cows and their F1 hybrid on milk fatty acid composition under grazing conditions. J. Dairy Sci. 93:2176-2184.

Palupi, E., A. Jayanegara, A. Ploeger, and J. Kahl. 2012. Comparison of nutritional quality between conventional and organic dairy products: A meta-analysis. J. Sci. Food Agric. http://dx.doi. org/10.1002/jsfa.5639.

Pape-Zambito, D. A., R. F. Roberts, and R. S. Kensinger. 2010. Estrone and 17 beta-estradiol concentrations in pasteurized-homogenized milk and commercial dairy products. J. Dairy Sci. 93:2533-2540.

Percival, H. J. 2003. Soil and soil solution chemistry of a New Zealand pasture soil amended with heavy metal-containing sewage sludge. Aust. J. Soil Res. 41:1-17. http://dx.doi.org/10.1071/sr01061.
Phillips, C. J. C., P. C. Chiy, D. R. Arney, and O. Kärt. 2000. Effects of sodium fertilizers and supplements on milk production and mammary gland health. J. Dairy Res. 67:1-12.

Piccand, V., E. Cutullic, S. Meier, F. Schori, P. L. Kunz, J. R. Roche, and P. Thomet. 2013. Production and reproduction of Fleckvieh, Brown Swiss, and 2 strains of Holstein-Friesian cows in a pasturebased, seasonal-calving dairy system. J. Dairy Sci. 96:5352-5363. http://dx.doi.org/10.3168/jds.2012-6444.

Pilarczyk, B., R. Pilarczyk, A. Tomza-Marciniak, A. Kowieska, J Wojcik, P. Sablik, A. Tylkowska, and D. Hendzel. 2011. Selenium concentrations in the serum and milk of cows from organic and conventional farms in West Pomerania. Tierarztl. Umsch. 64:327-331.

Pilarczyk, R., J. Wójcik, P. Czerniak, P. Sablik, B. Pilarczyk, and A. Tomza-Marciniak. 2013. Concentrations of toxic heavy metals and trace elements in raw milk of Simmental and Holstein-Friesian cows from organic farm. Environ. Monit. Assess. 185:8383-8392. http://dx.doi.org/10.1007/s10661-013-3180-9.

Powers, H. J. 2003. Riboflavin (vitamin B-2) and health. Am. J. Clin. Nutr. 77:1352-1360.

Prandini, A., S. Sigolo, and G. Piva. 2009. Conjugated linoleic acid (CLA) and fatty acid composition of milk, curd and Grana Padano cheese in conventional and organic farming systems. J. Dairy Res. 76:278-282. http://dx.doi.org/10.1017/S0022029909004099.

Qin, L. Q., X. P. Wang, W. Li, X. Tong, and W. J. Tong. 2009. The minerals and heavy metals in cow's milk from China and Japan. J. Health Sci. 55:300-305. http://dx.doi.org/10.1248/jhs.55.300.

Ramalho, H. M., S. D. Campos, S. Casal, R. Alves, and M. B. P. Oliveira. 2012. Lipid fraction quality of milk produced by Minhota (Portuguese autochthonous breed) compared to Holstein Friesian cow's. J. Sci. Food Agric. http://dx.doi.org/10.1002/jsfa.5713.

Rego, O. A., H. J. D. Rosa, S. M. Regalo, S. P. Alves, C. M. M. Alfaia, J. A. M. Prates, C. M. Vouzela, and R. J. B. Bessa. 2008. Seasonal changes of CLA isomers and other fatty acids of milk fat from grazing dairy herds in the Azores. J. Sci. Food Agric. 88:1855-1859. http://dx.doi.org/10.1002/jsfa.3289.

Revello Chion, A., E. Tabacco, D. Giaccone, P. G. Peiretti, G. Battelli, and G. Borreani. 2010. Variation of fatty acid and terpene profiles in mountain milk and "Toma piemontese" cheese as affected by diet composition in different seasons. Food Chem. 121:393-399. http://dx.doi.org/10.1016/j.foodchem.2009.12.048.

Rey-Crespo, F., M. Miranda, and M. López-Alonso. 2013. Essential trace and toxic element concentrations in organic and conventional milk in NW Spain. Food Chem. Toxicol. 55:513-518. http:// dx.doi.org/10.1016/j.fct.2013.01.040.

Richert, R. M., K. M. Cicconi, M. J. Gamroth, Y. H. Schukken, K. E. Stiglbauer, and P. L. Ruegg. 2013. Management factors associated with veterinary usage by organic and conventional dairy farms. J. Am. Vet. Med. Assoc. 242:1732-1743. http://dx.doi.org/10.2460/ javma.242.12.1732.

Rius, A. G., J. A. D. R. N. Appuhamy, J. Cyriac, D. Kirovski, O. Becvar, J. Escobar, M. L. McGilliard, B. J. Bequette, R. M. Akers, and M. D. Hanigan. 2010. Regulation of protein synthesis in mammary glands of lactating dairy cows by starch and amino acids. J. Dairy Sci. 93:3114-3127. http://dx.doi.org/10.3168/ jds.2009-2743.

Roche, J. R., L. R. Turner, J. M. Lee, D. C. Edmeades, D. J. Donaghy, K. A. Macdonald, J. W. Penno, and D. P. Berry. 2009. Weather, herbage quality and milk production in pastoral systems. 4. Effects on dairy cattle production. Anim. Prod. Sci. 49:222-232. http:// dx.doi.org/10.1071/ea07310.

Roderick, S., and J. Burke. 2004. Organic farming in Cornwall. Results of the 2002 Farmer Survey. Organic Studies Centre, Cornwall, UK.

Roesch, M., M. G. Doherr, and J. W. Blum. 2005. Performance of dairy cows on Swiss farms with organic and integrated production. J. Dairy Sci. 88:2462-2475.

Roesch, M., M. G. Doherr, W. Schären, M. Schällibaum, and J. W. Blum. 2007. Subclinical mastitis in dairy cows in Swiss organic and conventional production systems. J. Dairy Res. 74:86-92. http://dx.doi.org/10.1017/S002202990600210X. 
Rosati, A., and A. Aumaitre. 2004. Organic dairy farming in Europe. Livest. Prod. Sci. 90:41-51. http://dx.doi.org/10.1016/j.livprodsci.2004.07.005.

Sapru, A., D. M. Barbano, J. J. Yun, L. R. Klei, P. A. Oltenacu, and D. K. Bandler. 1997. Cheddar cheese: Influence of milking frequency and stage of lactation on composition and yield. J. Dairy Sci. $80: 437-446$.

Schönfeldt, H. C., N. G. Hall, and L. E. Smit. 2012. The need for country specific composition data on milk. Food Res. Int. 47:207-209. http://dx.doi.org/10.1016/j.foodres.2011.05.018.

Schröder, M., F. Yousefi, and W. Vetter. 2011. Investigating the dayto-day variations of potential marker fatty acids for organic milk in milk from conventionally and organically raised cows. Eur. Food Res. Technol. 232:167-174.

Shahbazkia, H. R., M. Aminlari, A. Tavasoli, A. R. Mohamadnia, and A. Cravador. 2010. Associations among milk production traits and glycosylated haemoglobin in dairy cattle; Importance of lactose synthesis potential. Vet. Res. Commun. 34:1-9. http://dx.doi. org/10.1007/s11259-009-9324-2.

Simopoulos, A. P. 2003. Importance of the ratio of $\omega-6 / \omega-3$ essential fatty acids: Evolutionary aspects. World Rev. Nutr. Diet. 92:1-22.

Simopoulos, A. P. 2010. The $\omega-6 / \omega-3$ fatty acid ratio: Health implications. Ol. Corps Gras Lipides 17:267-275. http://dx.doi. org/10.1684/ocl.2010.0325

Slots, T., G. Butler, C. Leifert, T. Kristensen, L. H. Skibsted, and J. H. Nielsen. 2009. Potentials to differentiate milk composition by different feeding strategies. J. Dairy Sci. 92:2057-2066. http:// dx.doi.org/10.3168/jds.2008-1392.

Slots, T., J. Sorensen, and J. H. Nielsen. 2008. Tocopherol, carotenoids and fatty acid composition in organic and conventional milk. Milchwissenschaft 63:352-355.

Smith, K. M., P. W. Abrahams, M. P. Dagleish, and J. Steigmajer. 2009. The intake of lead and associated metals by sheep grazing mining-contaminated floodplain pastures in mid-Wales, UK: I. Soil ingestion, soil-metal partitioning and potential availability to pasture herbage and livestock. Sci. Total Environ. 407:3731-3739. http://dx.doi.org/10.1016/j.scitotenv.2009.02.032.

Smith-Spangler, C., M. L. Brandeau, G. E. Hunter, J. Clay Bavinger, M. Pearson, P. J. Eschbach, V. Sundaram, H. Liu, P. Schirmer, C. Stave, I. Olkin, and D. M. Bravata. 2012. Are organic foods safer or healthier than conventional alternatives? A systematic review. Ann. Intern. Med. 157:348-366.

Soyeurt, H., P. Dardenne, F. Dehareng, C. Bastin, and N. Gengler. 2008. Genetic parameters of saturated and monounsaturated fatty acid content and the ratio of saturated to unsaturated fatty acids in bovine milk. J. Dairy Sci. 91:3611-3626. http://dx.doi. org /10.3168/jds.2007-0971.

Soyeurt, H., P. Dardenne, A. Gillon, C. Croquet, S. Vanderick, P. Mayeres, C. Bertozzi, and N. Gengler. 2006. Variation in fatty acid contents of milk and milk fat within and across breeds. J. Dairy Sci. 89:4858-4865.

Soyeurt, H., A. Gillon, S. Vanderick, P. Mayeres, C. Bertozzi, and N. Gengler. 2007. Estimation of heritability and genetic correlations for the major fatty acids in bovine milk. J. Dairy Sci. 90:44354442. http://dx.doi.org/10.3168/jds.2007-0054.

Steinshamn, H., and E. Thuen. 2008. White or red clover-grass silage in organic dairy milk production: Grassland productivity and milk production responses with different levels of concentrate. Livest. Sci. 119:202-215. http://dx.doi.org/10.1016/j.livsci.2008.04.004.

Stergiadis, S., C. J. Seal, C. Leifert, M. D. Eyre, M. K. Larsen, and G. Butler. 2013. Variation in nutritionally relevant components in retail Jersey and Guernsey whole milk. Food Chem. 139:540-548. http://dx.doi.org/10.1016/j.foodchem.2013.01.078.

Stiglbauer, K. E., K. M. Cicconi-Hogan, R. Richert, Y. H. Schukken, P. L. Ruegg, and M. Gamroth. 2013. Assessment of herd management on organic and conventional dairy farms in the United States. J. Dairy Sci. 96:1290-1300. http://dx.doi.org/10.3168/ jds.2012-5845.

Stoop, W. M., H. Bovenhuis, J. M. L. Heck, and J. A. M. van Arendonk. 2009. Effect of lactation stage and energy status on milk fat composition of Holstein-Friesian cows. J. Dairy Sci. 92:14691478. http://dx.doi.org/10.3168/jds.2008-1468.

Sundberg, T., B. Berglund, L. Rydhmer, and E. Strandberg. 2009. Fertility, somatic cell count and milk production in Swedish organic and conventional dairy herds. Livest. Sci. 126:176-182. http:// dx.doi.org/10.1016/j.livsci.2009.06.022.

Sundberg, T., L. Rydhmer, W. F. Fikse, B. Berglund, and E. Strandberg. 2010. Genotype by environment interaction of Swedish dairy cows in organic and conventional production systems. Acta Agric. Scand. A Anim. Sci. 60:65-73. http://dx.doi.org/10.1080/09064 702.2010 .496003 .

Swensson, C., and H. Lindmark-Mansson. 2007. The prospect of obtaining beneficial mineral and vitamin contents in cow's milk through feed. J. Anim. Feed Sci. 16:21-41.

Toledo, P., A. Andrén, and L. Björck. 2002. Composition of raw milk from sustainable production systems. Int. Dairy J. 12:75-80. http://dx.doi.org/10.1016/s0958-6946(01)00148-0.

Trachsel, P., A. Busato, and J. W. Blum. 2000. Body conditions scores of dairy cattle in organic farms. J. Anim. Physiol. Anim. Nutr. (Berl.) 84:112-124.

Tu, W. C., R. J. Cook-Johnson, M. J. James, B. S. Mühlhäusler, and R. A. Gibson. 2010. $\Omega-3$ long chain fatty acid synthesis is regulated more by substrate levels than gene expression. Prostaglandins Leukot. Essent. Fatty Acids 83:61-68. http://dx.doi. org/10.1016/j.plefa.2010.04.001.

US Government Printing Office. 2014. Electronic Code of Federal Regulations: Regulations of the Department of Agriculture: Subchapter M-Organic Foods Production Act Provisions. Vol. 2014.

Vaarst, M., and T. W. Bennedsgaard. 2001. Reduced medication in organic farming with emphasis on organic dairy production. Acta Vet. Scand. Suppl. 95:51-57. http://dx.doi.org/10.1186/17510147-43-S1-S51.

Valle, P. S., G. Lien, O. Flaten, M. Koesling, and M. Ebbesvik. 2007. Herd health and health management in organic versus conventional dairy herds in Norway. Livest. Sci. 112:123-132. http:// dx.doi.org/10.1016/j.livsci.2007.02.005.

van Hulzen, K. J. E., R. C. Sprong, R. van der Meer, and J. A. M. van Arendonk. 2009. Genetic and nongenetic variation in concentration of selenium, calcium, potassium, zinc, magnesium, and phosphorus in milk of Dutch Holstein-Friesian cows. J. Dairy Sci. 92:5754-5759. http://dx.doi.org/10.3168/jds.2009-2406.

Vanhatalo, A., T. Gäddnäs, and T. Heikkilä. 2006. Microbial protein synthesis, digestion and lactation responses of cows to grass or grass-red clover silage diet supplemented with barley or oats. Agric. Food Sci. 15:252-267. http://dx.doi.org/10.2137/14596060677.

Vetter, W., and M. Schröder. 2010. Concentrations of phytanic acid and pristanic acid are higher in organic than in conventional dairy products from the German market. Food Chem. 119:746-752. http://dx.doi.org/10.1016/j.foodchem.2009.07.027.

Vicini, J., T. Etherton, P. Kris-Etherton, J. Ballam, S. Denham, R. Staub, D. Goldstein, R. Cady, M. McGrath, and M. Lucy. 2008. Survey of retail milk composition as affected by label claims regarding farm-management practices. J. Am. Diet. Assoc. 108:1198-1203.

Villeneuve, M. P., Y. Lebeuf, R. Gervais, G. F. Tremblay, J. C. Vuillemard, J. Fortin, and P. Y. Chouinard. 2013. Milk volatile organic compounds and fatty acid profile in cows fed timothy as hay, pasture, or silage. J. Dairy Sci. 96:7181-7194. http://dx.doi. org/10.3168/jds.2013-6785.

Vlaeminck, B., V. Fievez, A. R. J. Cabrita, A. J. M. Fonseca, and R. J. Dewhurst. 2006. Factors affecting odd- and branched-chain fatty acids in milk: A review. Anim. Feed Sci. Technol. 131:389-417. http://dx.doi.org/10.1016/j.anifeedsci.2006.06.017.

Vyas, D., B. B. Teter, and R. A. Erdman. 2012. Milk fat responses to dietary supplementation of short- and medium-chain fatty acids in lactating dairy cows. J. Dairy Sci. 95:5194-5202. http://dx.doi. org/10.3168/jds.2011-5277.

Waiblinger, S., C. Menke, and G. Coleman. 2002. The relationship between attitudes, personal characteristics and behaviour of stockpeople and subsequent behaviour and production of dairy cows. 
Appl. Anim. Behav. Sci. 79:195-219. http://dx.doi.org/10.1016/ s0168-1591(02)00155-7.

Walker, G. P., F. R. Dunshea, and P. T. Doyle. 2004. Effects of nutrition and management on the production and composition of milk fat and protein: A review. Aust. J. Agric. Res. 55:1009-1028.

Wang, C., J. X. Liu, Z. P. Yuan, Y. M. Wu, S. W. Zhai, and H. W. Ye. 2007. Effect of level of metabolizable protein on milk production and nitrogen utilization in lactating dairy cows. J. Dairy Sci. 90:2960-2965.

Ward, N. I., R. R. Brooks, E. Roberts, and C. R. Boswell. 1977. Heavy-metal pollution from automotive emissions and its effect on roadside soils and pasture species in New Zealand. Environ. Sci. Technol. 11:917-920.

Wijesundera, C., Z. Shen, W. J. Wales, and D. E. Dalley. 2003. Effect of cereal grain and fibre supplements on the fatty acid composition of milk fat of grazing dairy cows in early lactation. J. Dairy Res. 70:257-265. http://dx.doi.org/10.1017/s0022029903006241.
Wiking, L., P. K. Theil, J. H. Nielsen, and M. T. Sørensen. 2010. Effect of grazing fresh legumes or feeding silage on fatty acids and enzymes involved in the synthesis of milk fat in dairy cows. J. Dairy Res. 77:337-342. http://dx.doi.org/10.1017/S002202991000021X.

Zagorska, J., and I. Ciprovica. 2005. The comparison of chemical pollution between organic and conventional milk. Pages 196-198 in Int. Sci. Conf. Proc., Univ of Agric., Latvia.

Zagorska, J., and I. Ciprovica. 2008. The chemical composition of organic and conventional milk in Latvia. Proc. 3rd Baltic Conference on Food Science and Technology. (FOODBALT-2008). Latvia University of Agriculture Faculty of Food Technology. 10-14.

Załecka, A., S. Bügel, F. Paoletti, J. Kahl, A. Bonanno, A. Dostalova, and G. Rahmann. 2014. The influence of organic production on food quality-Research findings, gaps and future challenges. J. Sci. Food Agric. http://dx.doi.org/10.1002/jsfa.6578. 